\title{
Labor Scarcity, Finance, and Innovation: Evidence from Antebellum America*
}

\author{
Yifei Mao \\ SC Johnson College of Business \\ Cornell University
}

\author{
Jessie Jiaxu Wang \\ W. P. Carey School of Business \\ Arizona State University
}

March 18, 2018

\begin{abstract}
This paper establishes labor scarcity as an important economic channel through which access to finance shapes technological innovation. We exploit antebellum America, a unique setting with (1) staggered passage of free banking laws across states and (2) sharp differences in labor scarcity between slave and free states. We find that greater access to finance spurred technological innovation as measured by patenting activities, especially in free states where labor was relatively scarce. Interestingly, in slave states where slave labor was prevalent, access to finance encouraged technological innovation that substituted for free labor, but discouraged technological innovation that substituted for slave labor.
\end{abstract}

Keywords: antebellum America, free banking laws, finance and innovation, labor scarcity

*We thank conference participants at WAPFIN@Stern, seminar participants at University of Calgary, and brownbag participants at Arizona State University and Cornell University for helpful comments. Contact information, Mao: ym355@cornell.edu; Wang: Jessie.Jiaxu.Wang@asu.edu. 


\section{Introduction}

While technological innovation is important for economic growth (Solow, 1957) and firms' competitive advantage (Porter, 1992), it is difficult to achieve. Pioneered by Schumpeter, a large literature has established a well-functioning financial market as a driver of technological innovation (King and Levine, 1993; Brown, Fazzari, and Petersen, 2009; Hall, 2010; Hsu, Tian, and Xu, 2014; Kerr and Nanda, 2015). However, the role of finance is rarely examined in connection with the fundamental incentive of innovation - reducing production costs. As argued by Rosenberg (1969) and Spence (1984), among others, the major incentive for firms to develop new technology is to gain competitive advantage by spending less on production. ${ }^{1}$ While financial market development contributes to higher capital supply, the degree to which firms utilize capital to advance innovation remains a question.

In this paper, we fill a gap in the literature by examining the marginal effect of finance on innovation in the presence of cost reduction incentives. In particular, we focus on labor scarcity, which leads to high labor costs and hence to strong incentives for firms to adopt labor-saving technologies.

We study a unique historical episode, antebellum America. This fascinating period in the 19th century, from just after the War of 1812 up to the beginning of the Civil War in 1860, provides a unique laboratory for our test. This period witnessed the staggered passage of the free banking laws across eighteen states, a unique setting in which to identify banking shocks. In early 1800s, banks were mainly local businesses, owing to information frictions, costs in transportation, and the dearth of interstate branching. Access to banks was difficult because the chartering process was cumbersome and corrupted, aiming at protecting the interests of incumbent banks. Between 1837 to 1860, eighteen states passed the free banking laws. The laws replaced individual charters with "free entry" upon a bank's satisfaction of standard requirements. The passage of the free banking laws encouraged bank entry and was a positive shock to a state' access to local

\footnotetext{
${ }^{1}$ Rosenberg (1969) argues what motivates inventors to invent certain things appearing throughout the 1800 s and early 1900s is that firms tried to invent labor-saving technology when labor was dear, and likewise when capital was dear. Spence (1984) establishes the importance of cost-reducing R\&D by showing that firms compete by expending resources with the purpose of reducing their costs. Mokyr (2010) documents the cost reduction of many goods due to technological innovation for 1750-1914, such as costs of fuel, steel, energy consumption, and transportation. Another example is the role of innovation in computer technology in reducing computational and labor cost, as documented and predicted by Moore's law (Schaller, 1997).
} 
finance.

Furthermore, labor scarcity differed significantly between the slave states in the South and the free states in the North. At the margin, "slave labor" in the South was less expensive than the "free labor" in the North. ${ }^{2}$ In other words, labor scarcity was more severe in the free states than in the slave states. The sharp contrast in labor scarcity was reinforced by the immobility of labor across regions during that time - another feature of antebellum America that is distinct from today's world.

To understand how access to finance affects innovation and the role of labor scarcity, we propose a stylized model. The model builds on Acemoglu (2010) and links the equilibrium innovation level with labor and finance. The economy has a monopolistic innovator who supplies labor-saving technology to final goods producers. ${ }^{3}$ The final goods producers combine labor and technology in production and maximizes profit by optimally choosing factor demand. Given producers' demand for technology and the development cost for innovation, the monopolistic innovator then optimally chooses the level of innovation and the monopolistic technology price. In particular, labor scarcity drives producers' demand for labor-saving technology; and greater access to finance reduces innovation costs for the innovator. We show that the equilibrium patenting outcome is jointly determined by labor scarcity and financing costs. The model has three predictions. First, greater access to finance spurs innovation. Second, if labor scarcity remains constant or becomes more severe when access to finance is greater, the equilibrium innovation level increases. Finally, if labor scarcity becomes less severe when access to finance is greater, then equilibrium innovation can actually decrease.

We combine several novel data sources to test the hypotheses. First, using digitalized historical patent filings from the United States Patent and Trademark Office, we collect data on the

\footnotetext{
${ }^{2}$ Free labor, as opposed to slave labor, refers to unforced labor. "Free labor" does not mean that the labor was free of charge; in fact, free labor was wage-earning.

${ }^{3}$ In this paper, we focus on labor-saving technologies which are substitutes of labor in production. While generally speaking technologies can also be labor complementary (e.g. as may be the case with computers complementing college graduates), the specific episodes of the 19th century America were mostly concerned with labor-saving technologies. The well-known Habakkuk hypothesis (Habakkuk, 1962) in economic history argues that the rapid technological progress in the 19th century US owned to labor scarcity, which acted as a powerful inducement for the adoption of labor-saving technologies, and more broadly for innovation. "...the dearness and inelasticity of American labour gave the American entrepreneur...a greater inducement than his British counterpart to replace labour by machines..." (Habakkuk, 1962, p. 17) In comparing labor-saving and labor-complementary technologies, Acemoglu argues: "It may well be that the technological advances of the late eighteenth and nineteenth centuries in Britain and the United States were strongly labor saving and did induce innovation and technology adoption..." (Acemoglu, 2010, p. 1040)
} 
historical patenting activities to proxy for technological innovation in the antebellum period. From the patent filings, we are able to identify, the county and state of the inventor who files the patent, the grant year and the technology class of the patent. Second, we collect data about the banks operating during the period from historical bank records. These historical records provide the name of the bank, its charter type, the location of operation, entry and exit dates, as well as detailed balance sheets. These detailed records allow us to directly observe changes in banking activities following the passage of the new banking laws. Finally, we obtain social and economic variables at the state level from the decennial census and the census of agriculture and manufacturing.

In the baseline analysis, we examine whether access to finance spurred innovation in antebellum America. We employ a difference-in-differences (DD) approach, taking advantage of the staggered passage of the free banking laws. Our baseline result shows that, after the passage of the free banking laws, the number of patents granted in a state increased significantly in the subsequent years. The economic magnitude was sizable. On average, a state that passed the free banking law generated 11.6 more patents in the third year following free banking, which accounts for $15.4 \%$ of the state-level patent variability. The results are robust to controlling for state fixed effects, year fixed effects, and time-varying state-level demographic and economic variables.

We then conduct a battery of tests to investigate whether our baseline results indeed show a causal impact of free banking on innovation. First, while the passage of free banking laws created exogenous changes to access to finance, state-level factors that manifested differently across states could have affected the timing of the banking reform. To mitigate the reverse causality concern, we employ the methodology of Bertrand and Mullainathan (2003) to examine the dynamics of innovation surrounding the passage of free banking laws. The innovation output shows no prior trend, indicating that reverse causality is unlikely to explain our results. Second, we conduct a placebo test by generating "pseudo" treated groups from the empirical distribution of years when states passed the free banking laws and re-estimating our baseline specifications: we conclude that the regression coefficients we estimate in our main tests are results that cannot occur mechanically in the data. Finally, we control for contemporaneous events that might have affected a state's innovation, such as usury laws and the presiding political party in a state. 
Our baseline results continue to hold with these controls, thus ruling out potential sources of confounding effects.

Having established that access to finance spurred innovation, we next turn to the role of labor scarcity as an important economic channel. Conjectured by our theoretical model, labor scarcity drives producers' demand for labor-saving technology and strengthens the causal impact of finance on innovation. To test this hypothesis, we first take advantage of the sharp differences in labor scarcity between the free and slave states. In free states where slavery was prohibited, production was carried out by "wage labor" and labor was relatively scarce. In contrast, in slave states, slaves not only provided labor that could not resign or demand higher wages, but ensured a source of labor for generations. In other words, there was higher labor scarcity in free states. We hypothesize that the impact of free banking was higher in free states, where labor was relatively scarce. This is indeed what we find.

To further pin down the labor scarcity channel, we introduce patent industry in a triple difference-in-differences (DDD) framework. Since free states and slave states differed in many dimensions other than labor scarcity, we introduce patent classification to control the comparison. In particular, we exploit the differences in the labor scarcity across agricultural industry and manufacturing industry in the free states and slave states. We find that, following the passage of free banking laws, the manufacturing patents in the free states experienced the highest increase. What is perhaps less expected is the response of innovation in slave states. While the manufacturing patents in the slave states increased with free banking, the agricultural patents actually experienced a slight decline.

The findings are consistent with the theoretical predictions. In the free states, free banking led to greater access to finance by merchants and manufacturers. The expansion of the manufacturing industry likely caused a higher degree of labor scarcity, which amplified the positive impact of free banking on innovation. In contrast, the effect of free banking in the slave states was mixed depending on how labor scarcity reacted to free banking. One possible explanation for the decline of agricultural patents is that access to finance further increased the slave labor population as banking made slavery investment and trade more convenient. With a greater supply of slave labor, incentives for innovation were further weakened. Indeed, we find an increase in slave labor following the passage of the free banking laws in a state. The results generally 
follow our model's conjecture that finance promotes innovation when labor is scarce and may impede innovation when labor becomes more abundant.

Although we have compared innovation across industries within the free and slave states, we are concerned that different states might have different industry concentrations, which could render innovation not comparable for these states. Hence, we further restrict the sample to states with similar industry concentrations in manufacturing and agriculture. Our results continue to hold in these subsample tests.

Having established the role of labor scarcity in how finance affects innovation, we take a step back and examine whether the passage of free banking laws did improve access to finance. We find that there was a significant increase in the number of free banks and the number of loans issued by free banks after the passage of the free banking laws. In addition, the impact of the free banking laws on access to finance and innovation was positive and significant when we only focus on slave states, suggesting the results are not driven by free states. Overall, the results indicate that the passage of free banking laws indeed led to an improvement in access to finance.

Taken together, our research sheds new light into factors driving technological innovation. The insights are useful today in explaining, for example, why some regions are more innovative than others, and under what conditions additional financing resources are effective in spurring innovation.

Our paper adds to the literature on the finance-growth nexus. This literature show a positive link between financial development and economic growth, both theoretically (Greenwood and Jovanovic, 1990; Bencivenga and Smith, 1991) and empirically (King and Levine, 1993; Jayaratne and Strahan, 1996; Levine, 1997; Beck, Levine, and Loayza, 2000; Black and Strahan, 2002; Kerr and Nanda, 2009). In particular, several studies use banking deregulation in the 1970s to 1990s U.S. to study the effect on innovation (Chava, Oettl, Subramanian, and Subramanian, 2013; Amore, Schneider, and Zaldokas, 2013; Cornaggia, Mao, Tian, and Wolfe, 2015; Hombert and Matray, 2016). In contrast to these studies, we take a historical approach and examine the antebellum setting using the staggered passage of the free banking laws as an exogenous shock to finance. This unique testing ground provides us new evidence on the impact of bank deregulation on technological innovation. Moreover, the immobility of labor and heterogeneity in labor scarcity across states allow us to establish labor scarcity as a new economic channel, 
absent from previous studies of the finance-innovation nexus.

Second, we provide empirical evidence linking labor scarcity and technology adoption. The idea dates back to Hicks (1932): "A change in the relative prices of the factors of production is itself a spur to invention, and to invention of a particular kind directed to economizing the use of a factor which has become relatively expensive." Following this insight, Acemoglu (2002, 2010) formalize the role of factor price in directing innovation and technical change. Bena and Simintzi (2017) use the 1999 U.S.-China bilateral agreement as a shock and find that using cheap and abundant offshore labor substitutes for labor-saving innovation. Neat historical settings also provide supporting evidence, such as the sudden drop in labor supply due to the Great Mississippi Flood of 1927 (Hornbeck and Naidu, 2014) and the reduction in cotton exports to Britain due to the U.S. Civil War (Hanlon, 2015). Adding to this literature, we provide new evidence confirming the role of labor scarcity in shaping innovation. Unlike earlier studies, our empirical setting features the interaction between labor scarcity and access to finance.

Finally, this study contributes to an assessment of the effect of free banking. The economic value of free banking, which some have nicknamed "wildcat banking," has been debated by economic historians. ${ }^{4}$ In particular, Jaremski and Rousseau (2013) study the effects of free banking on economic growth using decennial census data. Conclusions drawn from such studies are subject to data limitation since the law's passage was clustered in two decades and economic growth measures are only available at a decennial frequency. In contrast, patenting activity can be measured annually, which provides a more granular reflection of economic development via technological advances.

This paper proceeds as follows. Section 2 presents a historical discussion of antebellum America and the free banking laws. Section 3 sets up a model to analyze the effect on innovation of greater access to finance under different labor scarcity conditions. Section 4 describes our data. Section 5 presents the main empirical results on free banking and innovation, and Section 6 highlights labor scarcity as the key economic channel. Robustness and extensions are in Section 7. Section 8 concludes.

\footnotetext{
${ }^{4}$ See for example Rockoff (1972), Rockoff (1974), Rolnick (1983), Rolnick and Weber (1985), Jaremski (2010), Atack, Jaremski, and Rousseau (2014), and Mitchener and Jaremski (2015).
} 


\section{Historical Background}

\subsection{Antebellum America}

The antebellum era in the United States refers to the period from just after the War of 1812 until the beginning of the Civil War in 1860. During this period, the country experienced dramatic economic growth and innovation activity. The economy differed greatly across regions, especially between the free states in the North and the slave states in the South.

The North had abolished slavery and hence consisted of free states. The North enjoyed early industrialization, a rise in manufacturing, and urbanization. Manufacturing advances occurred in many industries, including textiles, machinery, and furniture. Industrialization also changed the concept of labor. The free (unforced) labor became wage earners. For example, textile factories trained employees to run the looms, giving rise to the concept of wage labor, which gradually began overtaking apprenticeships and family members as workforce sources.

In the agricultural South, slaves were the major labor force. The cotton boom made plantations profitable. Farmers obtained cheap land and used slave labor to grow and harvest the crops. Cotton growing became so profitable for the planters that it greatly increased their demand for both land and slave labor. In fact, most plantation owners' investments and wealth were in their slaves. With this continuing demand, the number of slaves in America grew from 700,000 in 1790 to 4 million in 1860.

Because slaves were denied formal education, slave labor contributed primarily to the lowskilled, agricultural labor force. Unlike wage laborers, slaves could not resign or demand higher wages, and their progeny ensured a supply of labor for generations (Conrad and Meyer, 1958; Fogel and Engerman, 1974; Fogel, 1977). The supply of slave labor was allocated by a system of regional specialization that produced slaves on the worn-out land of the Old South and the border states for export to the high-yield cotton fields of the Mississippi and Red River Valleys. ${ }^{5}$ Far from stagnating, the economy of the antebellum South grew rapidly. Between 1840 and 1860, per capita income increased more rapidly in the South than in the rest of the nation. By 1860

\footnotetext{
${ }^{5}$...the selling states include Virginia, Maryland, Delaware, North Carolina, Kentucky, and the District of Columbia; the buying states are assumed to be South Carolina, Georgia, Alabama, Mississippi, Tennessee, and Missouri. In 1830, Florida, and in 1850, Texas were added to the buying group. Tennessee, Missouri, and North Carolina are difficult to categorize; some parts of those states imported while other parts exported during the period (Collins, 1904).
} 
the South had attained a level of per capita income that was high by the standards of the time.

\section{$2.2 \quad$ Antebellum Innovations}

Innovation in the antebellum era was radical and unparalleled. Technological innovations, such as the steam engine, mechanical reaper, and sewing machine, reshaped the production process in and after the middle third of the 19th-century (see Thomson, 2004). The boom in patenting is consistent with an emphasis on demand-induced advances in inventive activity. As hypothesized by Habakkuk, "the dearness and inelasticity of American labour gave the American entrepreneur[...]a greater inducement than his British counterpart to replace labour by machines" (Habakkuk, 1962, p. 17). Rising labor costs acted as a powerful inducement for the invention and diffusion of labor-saving technologies. For example, Singer, in New York state, designed the first practical and efficient sewing machine. The improvement enabled a speed of 900 stitches per minute, greatly saved labor hours and revolutionized the textile industry. McCormick, who grew up in a slave-owning plantation in Maryland, invented the mechanical reaper. Farmers in Maryland did not show much interest. Later realizing the large demand in the growing Midwest, McCormick moved to Chicago and further patented improvements to his reaper technologies that revolutionized farming. ${ }^{6}$ Similarly, a series of inventions on cleaning and winnowing grain were patented in the states of New York, Pennsylvania, and Ohio, where farm labor was in scarcity. ${ }^{7}$

Notably, the growth in patenting was marked by a disproportionate increase in inventions by ordinary citizens with relatively common skills and limited wealth rather than by those with rare technical expertise or extensive financial resources (Sokoloff and Khan, 1990). ${ }^{8}$

Behind the strong innovative activity was a solid patenting system that transmitted knowledge of technological solutions and provided avenues for commercializing innovations. ${ }^{9}$ The Patent Act of 1790 was the first federal U.S. patent statute. The amendment of the act expe-

\footnotetext{
${ }^{6}$ For details see Miller (1997).

${ }^{7}$ In contrast, in the Southern plantations, winnowing was initially done by hand using winnowing baskets and then by winnowing barns, both replying intensively on slave labor (see Littlefield, 1991).

${ }^{8}$ Using U.S. patent records from 1790 to 1846, Sokoloff and Khan (1990) find shifts in the distributions of patentees from merchants/professionals to artisans/tradesmen and from urban to rural residents and a rising share of patents to patentees with no specialization and few patents over their careers.

${ }^{9}$ Cases of infringement were dealt with by a jury, which assessed the damages determined the appropriate punishment. The person who infringed was made to hand over all of the infringing devices to the owner of the patent.
} 
dited the examining process: on average, it took several months for a patent to be examined and granted once a written application was submitted.

\subsection{The Free Banking Laws}

In the early 19th century, access to banks was difficult. All new banks had to be chartered by a state legislature. There were usually only a few charter banks in each state. Unlike modern institutions, early banks rarely provided financial services to ordinary households in peripheral areas. Since traveling was relatively costly at that time, charter banks operated only in major cities. Except in a few southern states with statewide branch bank networks, new bankers entered local markets and banking was both legally and economically a local affair. Charters and corporate bylaws that restricted a bank's office to a specific place did not restrict its lending to that place, but information asymmetries narrowed the field of potential borrowers. Familiarity with customers was closely associated with geographic proximity because proximity lowered the cost of gathering information, monitoring borrowers, and enforcing the terms of the lending agreement. In 1836, a legislative committee from Rhode Island reported that "by far the greater part of the banks are, properly speaking, local, and managed for the accommodation of the people residing in or near the places of their location."(Congress, 1837, p. 44)

Several factors contributed to the limited access to finance. First, the chartering system was a tedious and cumbersome process that severely limited the number of banks opened. Second, the approval of a charter often depended on political influence and was aimed at protecting the interests of incumbent banks. Most of them enjoyed monopoly power and were able to charge high rates. As Hammond wrote, "It had long been difficult to get new bank charters in New York, because the [Albany] Regency kept the number down conservatively."(Hammond, 1957, p. 574) Third, the early charter banks conducted extensive insider lending: they lent a large proportion of their funds to members of their own boards of directors or to others with close personal connections to the boards (see Lamoreaux, 1986, 1996). ${ }^{10}$

The free banking laws initiated banking system reforms by eliminating the legislative charter requirement for a bank to be established. Starting with Michigan in 1837 and continuing through Pennsylvania in 1860, the free banking laws were passed in a staggered fashion in eighteen states.

\footnotetext{
${ }^{10}$ Lamoreaux (1996) traces the early history of the banking system to the antebellum era and documents the pervasiveness of insider lending.
} 


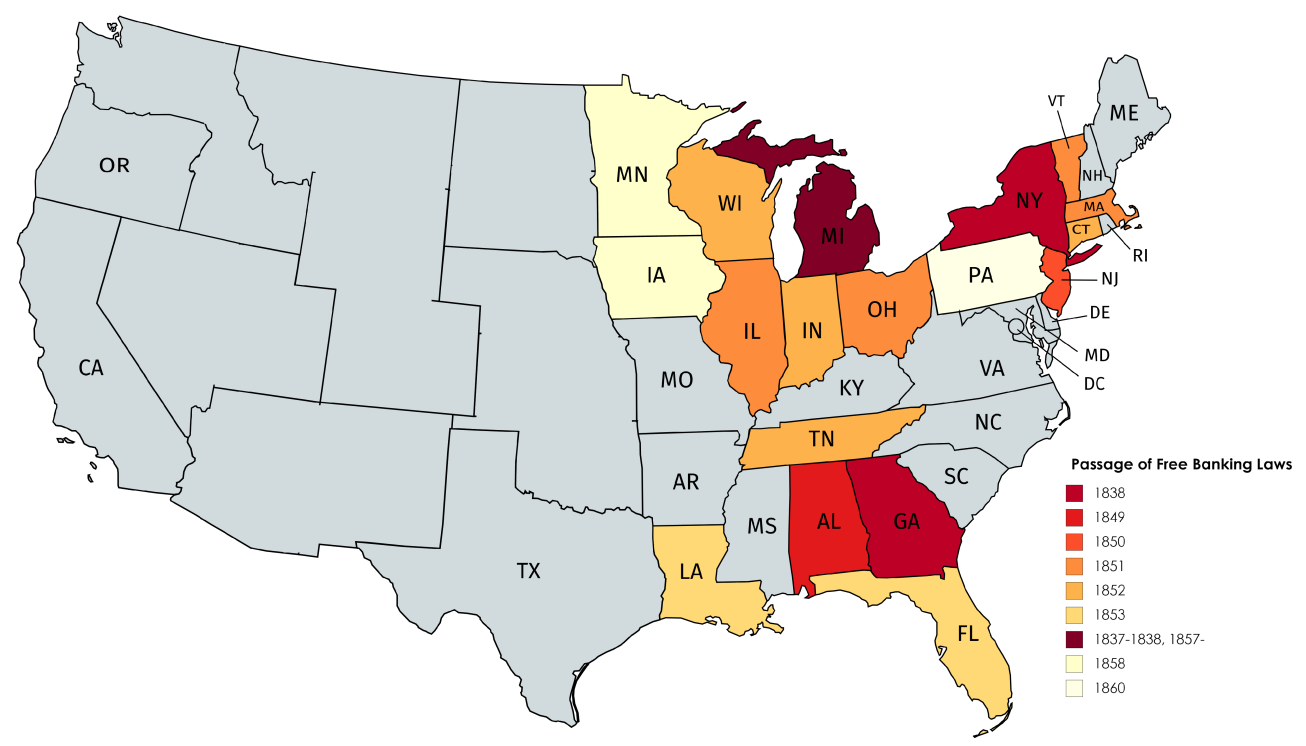

Figure 1. The Passage of the Free Banking Laws across States

Figure 1 shows a timeline of the staggered passage of the free banking laws. ${ }^{11}$ The laws replaced individual legislative charters with "free entry" upon a bank's satisfaction of the stipulated requirements. The new laws essentially allowed anyone who had the required paid-in capital to open a bank that could issue its own bank notes, take deposits, and make loans. The free banking era derived its name from this free entry provision of the general banking laws. ${ }^{12}$ Importantly, there was no longer political influence involved, allowing speedy bank entry with lower costs. This appealed both to Jacksonian Democrats, who believed the chartering process to be too monopolistic and aristocratic, as well as to the more commercially oriented Whig Party, who believed that the chartering process was too slow to address the financial needs of a rapidly expanding frontier region.

A state's passage of the free banking laws led to greater access to finance by merchants, manufacturers, and plantation owners in that state. Bank entry accelerated after the passage of the laws. The new banks had wider geographic coverage and a larger customer base than the ex-

\footnotetext{
${ }^{11}$ The states shown in the map were established as states or territories either before or during the free banking era and their economic data were included in the census beginning in 1850. For example, statehood was granted to California, Oregon, and Texas in 1850, 1859, and 1846 respectively.

${ }^{12}$ The free banking era was not a period of laissez-faire banking. The free banking laws attempted to protect the noteholders. While entry was unrestricted, banks established under the free banking laws were subject to strict oversight intended to insure the safely of free bank notes. First, free banks had to deposit designated state bonds as collateral for all notes issued. Second, they had to pay specie for notes on demand. Finally, free bank stockholders had double liability, i.e. they were liable for bank losses in an amount up to the value of their stock (see Rolnick, 1983).
} 
isting charter banks. To avoid direct competition with the existing banks, the new banks entered rural, previously unbanked areas, and encouraged the establishment of commercial businesses, manufacturing, and small businesses. ${ }^{13}$

Importantly, the exogenous nature of the law's passage across states provides us an identification strategy for access to finance. Historians have not yet reached consensus on the factors that determined where and when the laws were passed. In some states, the passage of the law was largely a response to political interference, corruption, and bargaining power between different political parties, whereas in other states, it seemed to be initiated by random events.

An interesting example is the state of New York. The law's passage in 1838 was triggered by an unlikely event, the kidnapping of a man named William Morgan after he threatened to reveal the secrets of the Masons. Investigations into the kidnapping implicated several famous Masons who were politically connected with the Regency. Legislative debates on banking policy became anti-Masonic. When the Regency lost support, the law was passed. In this regard, economist Bodenhorn refers to the "serendipitous nature of economic reform" (Bodenhorn, 2006, p. 21).

In our empirical analysis, we formally test and show that the passage across states cannot be explained by demographic and economic conditions, political factors, or other unobserved state-level characteristics.

\section{Model and Implications}

The model follows Acemoglu (2010). The goal is to understand the impact of greater access to finance on innovation, especially in conjunction with labor scarcity.

\subsection{Model Setup}

Environment The economy has a monopolistic innovator who develops patents and supplies technology to final good producers. The representative final goods producer has access to production function $\alpha^{-\alpha}(1-\alpha)^{-1} F(L, \theta)^{\alpha} q(\theta)^{1-\alpha}, \alpha \in(0,1)$. The final good production involves labor input $L$ and technology $\theta$ (such as the mechanical reaper in agriculture and the sewing machine in textile industry). $F$ is increasing and concave with both arguments. As argued in

\footnotetext{
${ }^{13}$ In its encouragement of small business, free banking advocates believed they had simultaneously addressed the issues of corruption, privilege, equality of opportunity, and protection of the public against incompetent bankers through the 100 percent note-collateral provision (Bodenhorn, 2006, p. 253).
} 
earlier sections, antebellum America was mostly concerned with demand-induced labor-saving technologies. Hence, we model technology $\theta$ as a labor-substitute such that $\partial^{2} F / \partial L \partial \theta<0$. The term $F$ needs to be combined with an intermediate good embodying technology $\theta$. The quantity of this intermediate good used by the representative final good producer is denoted by $q(\theta)$, conditioned on $\theta$ to emphasize that it embodies technology $\theta$. The term $\alpha^{-\alpha}(1-\alpha)^{-1}$ is included as a convenient normalization.

The technology is supplied by the monopolistic innovator. The initial research and development cost for the technology is $C(\gamma, \theta)$. The cost is increasingly convex with $\theta$. The parameter $\gamma$ summarizes the innovator's access to finance. Greater access to finance reduces innovation costs for the innovator, i.e., $\partial C(\gamma, \theta) / \partial \gamma<0$. Once developed and patented, the innovator has monopolistic power in the technology market. To capture the idea that technology has a nonrivalrous character and can thus be produced at relatively low cost once invented, let us assume that the intermediate good embodying technology $\theta$ can be produced at a constant per-unit cost normalized to $1-\alpha$ unit of the final good (this is again a convenient normalization). The unit price for the technology charged by the monopolistic innovator is denoted as $\chi$.

Finally, the labor supply $\bar{L}$ is exogenously given.

Optimization Taking wage $w$ and technology price $\chi$ as given, the representative final good producer optimally chooses labor and technology to maximize profits; thus, she solves the following problem:

$$
\max _{L, q(\theta)} \alpha^{-\alpha}(1-\alpha)^{-1} F(L, \theta)^{\alpha} q(\theta)^{1-\alpha}-w L-\chi q(\theta) .
$$

The first-order condition with respect to $q$ gives the optimal technology demand, an inverse demand curve with constant elasticity,

$$
q^{*}(\theta)=\alpha^{-1} F \chi^{-\frac{1}{\alpha}}
$$

Given producers' demand for technology in Eq. (2) and the development cost for innovation, the monopolistic innovator then optimally chooses the level of innovation $\theta$ and the monopolistic technology price $\chi$,

$$
\max _{\theta, \chi}(\chi-(1-\alpha)) q(\theta)-C(\gamma, \theta)
$$




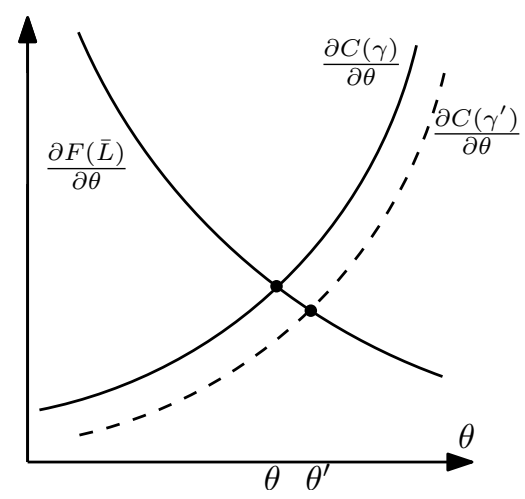

Figure 2. The Effect of Greater Access to Finance. This figure illustrates how the equilibrium innovation $\theta$ responds to greater access to finance. The horizontal axis represents $\theta$. The downward sloping curve, $\partial F(\bar{L}) / \partial \theta$, is the marginal product of labor. The upward sloping curve, $\partial C(\gamma) / \partial \theta$, is the marginal cost of innovation. Greater access to finance shifts the curve $\partial C(\gamma) / \partial \theta$ downward, moving $\theta$ to $\theta^{\prime}$.

Equilibrium An equilibrium in this economy consists of: the final good producer's decisions $\left\{L^{*}, q^{*}(\theta)\right\}$, the innovator's decisions $\left\{\theta^{*}, \chi^{*}\right\}$, and wage $w^{*}$, such that $L^{*}$ and $q^{*}(\theta)$ solve the producer's problem (1) given $w, \theta$, and $\chi ; \theta^{*}$ and $\chi^{*}$ solve the innovator's problem (3) given the technology demand $q^{*}(\theta) ; w^{*}$ satisfies labor market clearing such that $L^{*}=\bar{L}$.

Factors driving innovation First we plug the technology demand function (2) into the innovator's problem (3). This gives us the profit maximizing price of the innovator, $\chi^{*}=1$. Next we substitute the optimal monopolistic price $\chi^{*}$ and the technology demand function $q^{*}(\theta)$ into the innovator's problem. The innovator's decision then simplifies to $\max _{\{\theta\}} F(\bar{L}, \theta)-C(\gamma, \theta)$. Equivalently, the equilibrium innovation $\theta^{*}$ satisfies

$$
\frac{\partial F(\bar{L}, \theta)}{\partial \theta}=\frac{\partial C(\gamma, \theta)}{\partial \theta}
$$

From Eq. (4), access to finance and labor supply are two factors jointly determining innovation.

\subsection{Comparative Statics}

The comparative statics of the equilibrium have the following implications. The first implication is the effect of greater access to finance. Eq. (4) implies that in the model, $\partial \theta^{*} / \partial \gamma>0$. Other things equal, greater access to finance reduces innovation costs and spurs innovation. The effect is shown in Figure 2. The horizontal axis represents $\theta$. The downward sloping 


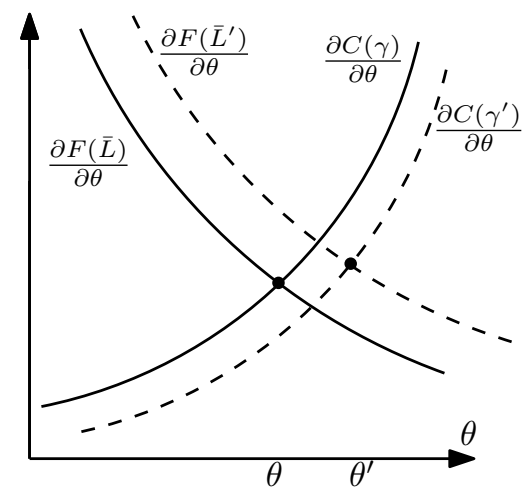

(a) More severe labor scarcity.

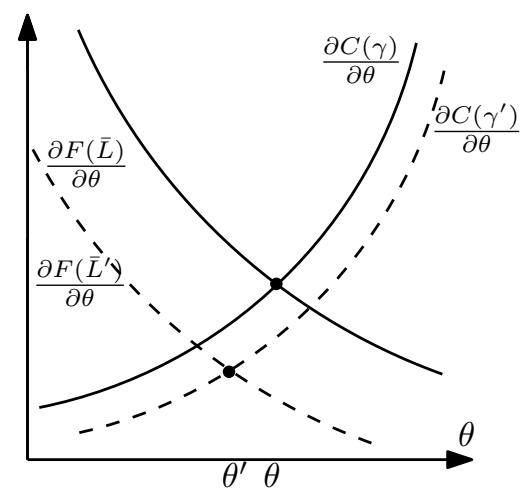

(b) Less severe labor scarcity.

Figure 3. Labor Scarcity and Greater Access to Finance. This figure illustrates how the equilibrium innovation $\theta$ responds to greater access to finance when labor scarcity condition also changes. In (a), labor scarcity becomes more severe with an increase in $\gamma$; in (b), labor scarcity becomes less severe with an increase in $\gamma$.

curve, $\partial F(\bar{L}) / \partial \theta$, is the marginal product of labor. The upward sloping curve, $\partial C(\gamma) / \partial \theta$, is the marginal cost of innovation. The equilibrium level of innovation is achieved where the two curves cross. With greater access to finance, the innovation costs decrease; hence, $\partial C(\gamma) / \partial \theta$ shifts downward, leading to a higher level of innovation.

The implications are more subtle when labor supply interacts with access to finance. If labor supply decreases or remains unchanged following greater access to finance, the equilibrium innovation level increases. This is shown in Figure 3a. A more severe labor scarcity shifts the marginal product of labor upwards, further increasing $\theta$. An interesting case is when labor scarcity becomes milder following greater access to finance. As shown in Figure 3b, larger labor supply pushes the marginal product of labor downward. If this channel dominates, the equilibrium innovation could decrease, despite a drop in innovation costs.

Let us apply the model's implications to antebellum America. In the industrial North, free banking led to greater access to finance by local merchants and manufacturers. The expansion of businesses and the boom in industrialization likely posed a higher degree of labor scarcity. From Figure 3a, we should expect an increase in innovation, unambiguously. The effect on technologies that substituted for free labor in the South would be similar. In contrast, the technologies that substituted for slave labor in the South would be an exception. If an increase in slave labor coincided with free banking, even if not causal, we could expect a decrease in technologies that substituted for slave labor. 


\section{Data and Summary Statistics}

Our data span from 1812 to 1860 . We use a combination of data sources to study how access to finance affects innovation, and the role of labor scarcity in shaping this relation. We next describe the data sources and provide summary statistics.

\subsection{Patents}

We use historical patenting activity to proxy for technological innovation in the antebellum period. The source is digitalized historical patent filings from the United States Patent and Trademark Office. The historical records provide the year in which the patent was granted, the state and county where the inventor resided, and the technology class the patent belonged to. ${ }^{14}$ The blue dotted curve in Figure 4 shows the natural log of total patent counts by year from 1812 to 1860 . While the initial growth was slow, a span of rapid growth in patenting coincided with the economic recovery of the early 1820s. As the upturn in the economy continued, patenting increased steadily until a change in the patent system in July 1836 introduced more stringent requirements (Sokoloff and Khan, 1990). The number of patents awarded fell immediately and then stabilized at this lower level for nearly eight years. The economic contraction that began with the Panic of 1837 and persisted through the early 1840s played some role in accounting for a second spell of stagnation in patenting starting in the late 1830s. Notably, the growth rate of patent counts beginning in 1850 exceeds any modern-day growth.

Information on the technology class the patent belonged to allows us to identify technologies used in the agricultural industry and manufacturing industry, respectively. We begin by mapping the USPTO technology classes into two-digit technological sub-categories and six main categories following Hall and Jaffe (2001). Agricultural patents then consist of those that fall into sub-category 11 (Agriculture, Food, Textiles) and 61 (Agriculture, Husbandry, Food). Manufacturing patents consist of those that fall into main category 5 (Mechanical) as well as sub-category 63 (Apparel \& Textile). ${ }^{15}$ The red dotted curve and the green dashed curve in Figure 4 show the $\log$ of agricultural patents and manufacturing patents, respectively. The manufacturing patents

\footnotetext{
${ }^{14}$ Information regarding patent citation or application year is not available for historical patents in the Antebellum era.

${ }^{15}$ Some other sub-categories potentially do not pertain to labor-saving technologies, such as sub-category 31 (Drugs), 42 (Electrical Lighting), 45 (Power Systems), and 62 (Amusement Devices).
} 


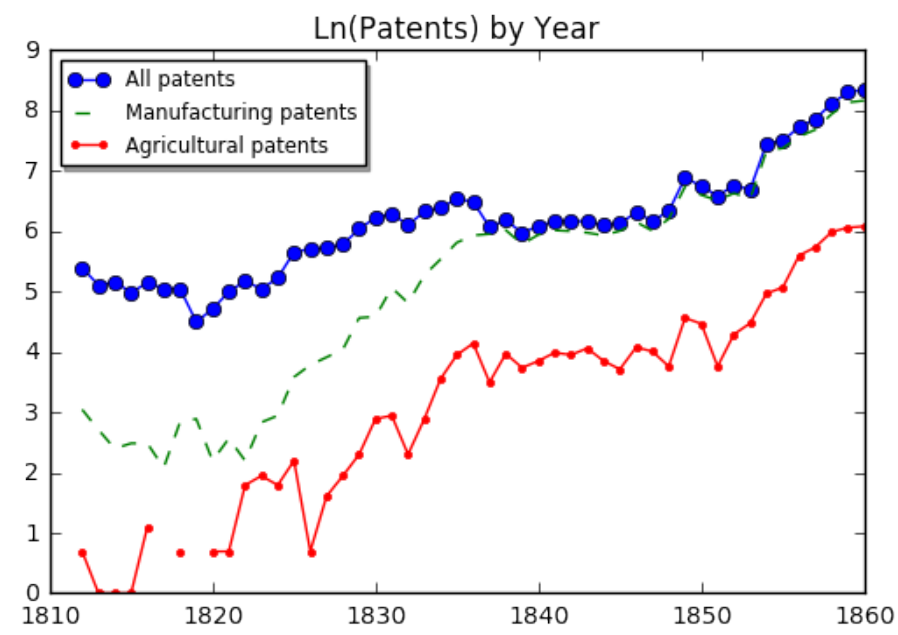

Figure 4. The Total Number of Patents Granted. The blue dotted curve shows the natural $\log$ of total patent counts by year from 1812 to 1860. The red dotted curve and the green dashed curve show the natural log of agricultural patents and manufacturing patents, respectively.

had a larger quantity and experienced faster growth than the agricultural patents.

While we acknowledge that simply counting the number of patents could miss certain valuable inventions, it seems to be a reasonable and the best available measure of antebellum innovation. Economic historians studying pre-Civil War invention and productivity look primarily at patent counts. They argue that patenting, though an imperfect measure, should be qualitatively representative of the resources consumed in inventive activity (Griliches, 1990). For example, using census data, Sokoloff (1992), shows that patenting was a major driver of antebellum total factor productivity at the cross section.

In using the location of the patents, we implicitly assume that the location where the patent was filed proxies for the location where the technology was adopted, at least at the initial marketing stage. Indeed, with high transportation costs, the technology market was frictional and segmented during that time. Lamoreaux and Sokoloff (2000) use industry directories to map the location of the firms using the most advanced technologies. They also use trade journal accounts to track the geographic origins of the most important inventions in an industry. They confirm that both sources correspond closely with the distribution of patents, suggesting that the location of inventions was consistent with the location of technology adoption. 


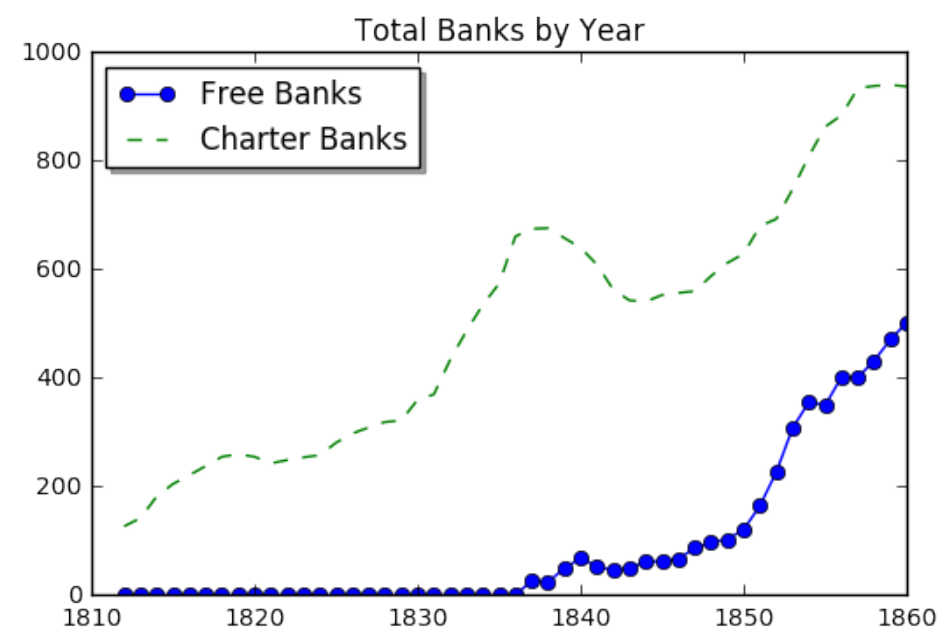

Figure 5. The Total Number of Banks Operating. The blue dotted curve and the green dashed curve show the total number of free banks and charter banks by year, for the period of $1812-1860$.

\subsection{Historical Bank Records}

We obtain information for banks from Weber $(2006,2008)$ complemented with historical bank records-i.e., Archived Reported Balance Sheets of State Banks to state authorities. ${ }^{16}$ These historical records provide the name of the bank, its charter type, the location of operation, entry and exit dates, and detailed balance sheets. Figure 5 shows the total number of free banks (in blue) and charter banks (in green) by year, for the period of 1812-1860. From the figure, we can make the following observations. First, charter banks constituted the majority of the bank population. Second, free banks began to appear in 1837 (the year the first free banking law was passed) and increased sharply in number as the law was approved in subsequent states. Finally, after the implementation of the free banking laws, the increase in the total number of banks was driven mostly by the entry of the free banks.

Conditional on passing the free banking laws, ten states had significant free banking activity, whereas eight states had relatively little free bank entry (Rockoff, 1974). The estimated growth rate of free banks is nineteen per year when including controls and year and state fixed effects. When comparing the balance sheets of the free banks with the charter banks, the average size of free banks in total assets and loans was slightly smaller than that of the charter banks, but

\footnotetext{
${ }^{16}$ We thank Matthew Jaremski for sharing with us the information on bank charter type.
} 
comparable.

\subsection{Historical Census Records}

We obtain social and economic variables at the state level from the decennial census of 1810-1860, and the Census of Agriculture in 1840, 1850, and 1860. Given that the variables are decennial, we interpolate them to individual years. In particular, we use the following variables: population, urban population, slave population, white population. In our robustness analysis, we control for economic and industrial characteristics at the state level by using agricultural and manufacturing output.

A state is included in our sample starting from the establishment of the territory or statehood whichever is earlier. ${ }^{17}$ We also include a dummy variable that characterizes whether a state is a slave or a free state based on Wagner, Gallagher, and Finkelman (2009). The list of states is provided in Appendix A. The slave and free states differ significantly in the degree of labor scarcity. In addition to comparing the demographic features, we take the available wage measures from the decennial census (in 1850 and 1860), including average wages to a day laborer (with board) and average wages to a day laborer (without board).

\subsection{Summary Statistics}

The summary statistics are provided in Table 1 Panel A. On average, a state in our sample had 25.14 granted patents per year. Among them, 2.27 patents are classified as agricultural patents, and 10.19 patents are classified as manufacturing patents. The average population in a state was 1.1 million. Among them, $12 \%$ was urban population, $15 \%$ was slave population, and $82 \%$ was white population. On average, there were 3.04 free banks in each state and $\$ 1.3$ million loans issued by free banks each year. The definition of the variables is provided in Appendix B.

\section{Free banking and Innovation}

\subsection{Baseline Specification and Results}

To assess the impact of access to finance on innovation, we estimate the following empirical model:

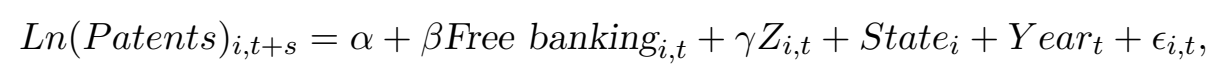

\footnotetext{
${ }^{17}$ The date of statehood information is obtained from www.history.com/topics/us-states.
} 
where $i$ indexes state, $t$ indexes time, and $s$ is equal to one, two, or three. The dependent variable in Eq. (5) is the natural logarithm of one plus the total number of patents generated in a state in the following one, two, and three years, respectively. We use a dummy variable, Free banking $_{i, t}$ to capture the status of passage of the free banking law in state $i$ year $t . Z_{i . t}$ is a vector of controls that include total state population, white population ratio, urban population ratio, and slave population ratio in state $i$ year $t$. Year end $_{t}$ atate ${ }_{i}$ capture year and state fixed effects, respectively. We cluster standard errors by year in our baseline tests.

We include state-level controls to absorb the time-varying demographic and economic conditions which could be associated with the inventive opportunities of a state. We include population and urbanization following Higgs (1971). In the absence of a mass communications system, the locational distribution of actual inventive opportunities coincided with that of the population. ${ }^{18}$ The slave and white populations reveal, to a large extent, the local educational attainment, social class structure, and division of labor.

We also include the state fixed effects. This helps to address the concern that unobservable variables omitted from Eq. (5) which generate variation in a state's stance toward openness to free banking law might be correlated with innovativeness, rendering our findings spurious. For example, if states with vibrant economic activities and strong growth opportunities were more likely to pass free banking laws, then the unobservable state-level economic activity and growth opportunities could correlate with both innovativeness and Free banking, which could bias our coefficient estimate of Free banking downward. Including state fixed effects will strip out any persistent differences across states.

We report the OLS regression results estimating Eq. (5) in Table 2. The coefficient estimates of Free banking are positive and significant at the $1 \%$ level. This finding suggests that the passage of free banking laws led to an increase in the number of patents in the first three subsequent years. To be more concrete, based on the coefficient estimate of Free banking in column (6), states that passed the free banking law generated a total of $46.3 \%$ more patents in the third year than states that did not pass the free banking laws. The effect of free banking laws on patent quantity was economically sizable: the above increase translates to an increase

\footnotetext{
${ }^{18}$ Higgs (1971) shows that the proportion of the population in urban areas and the number of inventions per capita were closely associated during the 1870-1920 period for a cross section of American states.
} 
of 11.6 patents three years after the passage of the free banking law. (Table 1 shows the average number of patents granted in a state was 25.1. The product of 25.1 and $46.3 \%$ is 11.6.) This increase in patent quantity accounted for $15.4 \%(=11.6 / 75.4)$ of the state-level patent variability, a significant margin.

\subsection{Additional Endogeneity Tests}

\subsubsection{Temporal Dynamics of Innovation}

In the historical background, we have argued that the staggered passage of the free banking laws represented a plausibly exogenous shock to access to finance. Nonetheless, it is likely that state-level factors that manifest differently across states could have affected the timing of the passage of free banking laws in different states. A reverse causality concern may arise if the states also differ in their innovation intensity and such differences triggered the passage of free banking law. To further explore the possibility of reverse causality, we follow Bertrand and Mullainathan (2003) to examine the dynamics of innovation prior to the free banking laws. We decompose Free banking into four dummy variables associated with four periods around the free banking laws: all years up to and including one year prior to free banking, one year after free banking, two years after free banking, and three years or more after free banking. The year in which the free banking law was passed was the reference year in this setting. We estimate the following model:

$$
\begin{aligned}
\operatorname{Ln}\left(\text { Patents }_{i, t+1}=\right. & \alpha+\beta_{1} \text { Before }_{i, t}^{1-}+\beta_{2} \text { After }_{i, t}^{1}+\beta_{3} \text { After }_{i, t}^{2}+\beta_{3} \text { After }_{i, t}^{3+} \\
& +\gamma Z_{i, t}+\text { State }_{i}+\text { Year }_{t}+\epsilon_{i, t} .
\end{aligned}
$$

In Panel B of Table 3 we report the regression results estimating Eq. (6). Across all specifications, the coefficient estimate of $\operatorname{Before}_{i, t}^{1-}$ is not significant, suggesting that statelevel innovation showed no significant change prior to the passage of free banking laws. The coefficient estimates of After ${ }^{1}$, After $^{2}$, and $A$ fter $^{3+}$ are positive and significant, consistent with our baseline findings. These results alleviate concerns about reverse causality and suggest that the innovation only increased after free banking. 


\subsubsection{Falsification Test}

Another concern that could prevent us from drawing a causal interpretation of free banking laws on innovation is an omitted variables problem: unobserved shocks or variables that are omitted from our analysis but coincide with state-level free banking events could be driving our results. To resolve this concern, we conduct placebo tests to check whether our results disappear when we artificially assume that free banking laws occurred in years other than the actual passage year. We do this by first obtaining an empirical distribution of years when states passed the free banking laws. We then randomly assign states to each of these passage years (without replacement) following the empirical distribution. This approach maintains the distribution of free banking years from our baseline specification, but it disrupts the proper assignment of free banking years to states. Therefore, if an unobservable shock occurred at approximately the same time as the free banking laws, it should still reside in the testing framework and thus have an opportunity to drive the results. However, if no such shock exists, then our incorrect assignments of free banking years to states should weaken our results when we re-estimate our baseline regressions in Eq. (5). We report the results in Table 4. The coefficient estimates of Free banking are statistically insignificant and not different from zero in all columns, providing support that it is free banking that impacted innovation rather than other shocks.

\subsubsection{Evidence Against Alternative Interpretations}

Although our falsification test alleviates concerns about confounding effects from contemporaneous events, we conduct additional robustness tests to rule out potential sources of confounding effects.

State Usury Laws. One event that could have taken place simultaneously with the passage of free banking laws was a change in state usury laws. Usury laws limit the maximum interest rate banks can charge on loans. As argued by Benmelech and Moskowitz (2010), usury laws limited the maximum legal interest rate, causing credit rationing. They show that usury laws in the 19th century reduced credit and economic activity when they were binding. The alternative hypothesis is that it was the relaxation of usury laws rather than the free banking laws that led to an increase in innovation: in states with a higher maximum legal interest rate, banks lent with lower restrictions to high-risk entrepreneurs, encouraging innovation. Data on the maximum 
legal rates come from Holmes (1892). We control for the effect of usury laws in estimating Eq. (5) and examine whether they could absorb the impact of the free banking law. Panel $\mathrm{C}$ of Table 3 reports the results with usury laws controls in columns 1-3. The results indicate that the impact of free banking on innovation was not absorbed by usury laws.

Political Parties in Power. Another factor potentially related to both innovation and banking was the alternation of state-level political parties in power. In particular, the Whig Party, a political party active in the middle of the 19th century, favored modernization, banking, and economic protectionism to stimulate manufacturing. It appealed to entrepreneurs, planters, reformers, and the emerging urban middle class, but had little appeal to farmers or unskilled workers. ${ }^{19}$ Potentially, the probanking Whig Party's election in a state led to both the passage of the free banking laws and other regulations that encouraged entrepreneurship. To investigate this issue, we control for state-level political party in columns 4-6 of Panel C of Table 3. The data are from the historical record on the governors of the states in The Tribune Almanac and Political Register. ${ }^{20}$ The dummy variable equals 1 if the state governor belonged to any of the following parties: Whig, Anti-Masonic, Republican, American, Know-nothing, Constitutional Union Party, National Union Party. Results show that the impact of the free banking laws on innovation remain positive and significant after controlling for the state-level political parties in power.

Overall, the results confirm the causality that greater access to finance brought by free banking spurred innovation.

\section{The Role of Labor Scarcity}

Our evidence so far shows a robust, positive effect of state-level free banking laws on innovation, which did not appear to be driven by pre-existing trends in innovation output prior to free banking or by omitted shocks coinciding with the free banking laws. In this section, we explore an important underlying economic channel that shaped how free banking laws affected

\footnotetext{
${ }^{19}$ The Whig Party emerged in the 1830 s as the leading opponent of Jacksonians, supporters of the policies of President Andrew Jackson (in office 1829-37) and his Democratic Party. It included former members of the National Republican and Anti-Masonic Parties. Along with the rival Democratic Party, it was central to the Second Party System from the early 1840s to the mid-1860s.

${ }^{20}$ The Tribune Almanac and Political Register kept a record of the name, party, year elected, and salary of the governor in each state since the establishment of the statehood.
} 
innovation outcome: labor scarcity.

\subsection{Comparing Free States and Slave States}

As demonstrated in our theoretical model, labor scarcity is an important factor that determines how access to finance affects innovation. However, it is difficult to empirically test it in today's world because labor is mobile across regions. The antebellum period provides a unique laboratory in which to test the importance of labor scarcity. During this historical episode, free states and slave states coexisted. At the margin, slave labor in the South was less expensive than free labor in the north. In other words, the scarcity of labor in production was generally higher in the free states. This historical setting provides us with a natural degree of heterogeneity in labor scarcity across regions.

Table 4 reports the summary statistics of labor conditions in the free states and slave states. Free states and slave states had similar levels of population, but the composition of the population was very different. Free states had a higher ratio of urban population to total population and a higher ratio of white people to total population; they also paid a higher daily average wage to individual laborers. The evidence is consistent with our conjecture that free states faced a higher degree of labor scarcity than the slave states.

We are interested in whether and how being a free state or not affects the marginal impact of free banking laws on innovation. To this end, we estimate the following model:

$$
\begin{aligned}
& \operatorname{Ln}\left(\text { Patents }_{i, t+s}=\alpha+\beta_{1} \text { Free banking }_{i, t} \times \text { Free state }_{i, t}+\beta_{2} \text { Free banking }_{i, t}+\beta_{3} \text { Free state }_{i, t}\right. \\
& +\gamma Z_{i, t}+\text { State }_{i}+\text { Year }_{t}+\epsilon_{i, t}
\end{aligned}
$$

where $i$ indexes state, $t$ indexes time, and $s$ is equal to one, two, or three. The dependent variable captures state-level innovation outcomes as measured by patent counts. We add a new variable, Free state $_{i, t}$, and the interaction term between Free banking ${ }_{i, t}$ and Free state ${ }_{i, t}$. The coefficient estimate on the interaction term $\beta_{1}$ reflects the effects of the free banking laws on innovation in free states (relative to slave states). If the more pronounced labor scarcity in production of the free states posed a stronger incentive to innovate, we should expect $\beta_{1}$ to be positive and significant.

We report the results estimating Eq. (7) in Table 5. The coefficient estimates of Free banking ${ }_{i, t} \times$ 
Free state $i, t$ are positive and significant at the $1 \%$ level. Based on the coefficient estimate reported in column (3), free states with free banking laws generated a total of $55.8 \%$ more patents than slave states with free banking in the third year following the law passage. Overall, these findings show that free banking enhanced innovation more significantly in free states than in slave states, confirming that access to finance has a larger impact on innovation under labor scarcity.

\subsection{Triple Difference-in-differences: Introducing Industry Classification}

Free states and slave states differed in many dimensions in addition to labor scarcity conditions. Hence one potential concern is that we capture a factor that did not pertain to labor scarcity. To address this concern, we introduce patent industries in the analysis to control the comparison. Differences in labor scarcity across industries and states present a unique opportunity for us to pin down the labor scarcity channel. In particular, we make use of the differences in relative labor scarcity across free labor and slave labor in free states and slave states, respectively. In free states, the system of wage-earning free labor led to a scarcity in labor supply, especially in the fast-growing manufacturing industry. In slave states, labor was less scarce in general; importantly, there was relatively abundant slave labor that constituted the main work force of the agricultural industry. Therefore, we could rank the degree of labor scarcity within each state and industry bracket in the following ascending order: agricultural industry in slave states, manufacturing industry in slave states, agricultural industry in free states, and manufacturing industry in free states.

According to the rank of labor scarcity, we have the following conjectures: Upon free banking, (1) within slave states, the innovation could experience a decrease in the agricultural industry where labor was abundant; (2) within agricultural industry, there was a greater increase in innovation in free states relative to slave states; (3) within slave states, there was a greater increase in innovation in the manufacturing industry relative to agricultural industry; (4) the highest innovation increase was in manufacturing industry in the free states, where labor was most scarce. We test these above hypotheses by estimating a triple difference-in-differences (DDD) model as in Chetty, Looney, and Kroft (2009) and Gruber (1994). The model is as 
follows:

$$
\begin{aligned}
\text { Ln }(\text { Patents })_{i, j, t+s}= & \alpha+\beta_{1} \text { Free banking }_{i, t}+\beta_{2} \text { Free banking }_{i, t} \times \text { Free state }_{i, t} \\
& +\beta_{3} \text { Free banking }_{i, t} \times \text { Manufacturing patent }_{j} \\
& +\beta_{4} \text { Free banking }_{i, t} \times \text { Free state }_{i, t} \times \text { Manufacturing patent }_{j} \\
& +\beta_{5} \text { Free state }_{i, t} \times \text { Manufacturing patent }_{j}+\beta_{6} \text { Free state }_{i, t} \\
& +\beta_{7} \text { Manufacturing patent }_{j}+\gamma Z_{i, t}+\text { State }_{i}+\text { Year }_{t}+\epsilon_{i, j, t},
\end{aligned}
$$

where $i$ indexes state, $t$ indexes year, $j$ indexes patent technology category, and $s$ is equal to one, two, or three. The coefficient estimate $\beta_{1}$ captures the impact of free banking on agricultural innovation in slave states. The coefficient estimate $\beta_{2}$ is the "within agricultural industry" DD estimate of the impact of free banking on innovation, reflecting the effects of the free banking laws on agricultural innovation for free states (relative to slave states). The coefficient estimate $\beta_{3}$ is the "within slave states" DD estimate of free banking on innovation, measuring the effects of free banking on manufacturing innovation (relative to agricultural innovation) in slave states. The DDD estimate $\beta_{4}$ measures the impact of free banking on manufacturing innovation (relative to agricultural innovation) in free states (relative to slave states). If our conjecture is correct, we should expect to see a negative $\beta_{1}$, a positive $\beta_{2}$, a positive $\beta_{3}$, and a positive $\beta_{4}$.

We report the regression results estimating Eq. (8) in Table 6. The coefficient estimate $\beta_{1}$ is indeed negative and significant at $1 \%$ significance level, suggesting that slave states experienced a drop in agricultural innovation following the passage of free banking. The coefficient estimate $\beta_{2}$ is positive and significant at $1 \%$ level, suggesting that free banking's effects on agricultural innovation were higher in free states than in slave states. The coefficient estimate $\beta_{3}$ is positive and significant at $1 \%$ level, suggesting that free banking's effects on manufacturing innovation were higher than agricultural innovation in slave states. The coefficient estimate $\beta_{4}$ is positive and significant at $1 \%$ level, suggesting that the differential effects of the free banking laws on manufacturing innovation relative to agricultural innovation were higher in free states than in slave states.

The results are consistent with our conjectures. These results confirm that the free banking laws promoted innovation when labor was scarce, and further suggest that free banking dis- 
couraged innovation where labor was plentiful and the marginal cost of labor was low - in the agricultural industry of slave states.

\subsection{Banking and Slavery in the South}

The result that free banking discouraged agricultural innovation in slave states contains an important insight. It suggests that greater access to finance did not necessarily promote innovation. One possible explanation for the decline of agricultural patents is that access to finance further increased the slave labor population as banking made slavery investment and trade more convenient. Banks' involvement with slave mortgaging occurred throughout the antebellum era and across the slave states. Many helped to underwrite the sale of slaves, using them as collateral and they were willing to sell slaves as part of foreclosure proceedings on anyone who failed to fulfill a debt contract. ${ }^{21}$ While most of the direct historical records in early decades of the antebellum era concerned slave financing through traditionally-chartered banks (e.g. Murphy, 2017), the connectivity of the banking sector implies indirect relations between all southern banks and slavery.

An alternative explanation is that greater access to finance in a slave state might attract more slave holders and slaves to a state that passed the free banking laws (Fogel and Engerman, 1974). In both cases, free banking increased slave labor and further discouraged innovation. To verify the channel, we examine total changes in the slave population across states and find an increase in the slave population after free banking passage in Table $7 .{ }^{22}$ Taken together, finance promotes innovation when labor is scarce and may impede innovation when labor becomes more abundant.

\subsection{Robustness: Controlling for Industry Concentration}

One potential concern about the current results is that slave and free states were vastly different in economic conditions and industry composition, and these factors, rather than the difference in labor scarcity, could drive our results. We next conduct additional robustness tests to ensure that our results are not driven by the difference in industry concentration between

\footnotetext{
${ }^{21}$ See for example discussions in Stone (1915), Martin (2010), Depuydt (2013), Gonzalez, Marshall, and Naidu (2017)

${ }^{22}$ The census reports slave population per state decennially, hence the data in our regression are for the slave populations in 1810, 1820, 1830, 1840, 1850, and 1860 .
} 
free and slave states.

Table 8 reports results estimating Eq. (8) for the subsamples. Panel A imposes the restriction that the states included should have agricultural output less than manufacturing output. The results are qualitatively similar to those in Table 6 . The coefficient estimates on Free banking $g_{i, t}$ and other variables are dropped due to a lower power of the tests with fewer state observations.

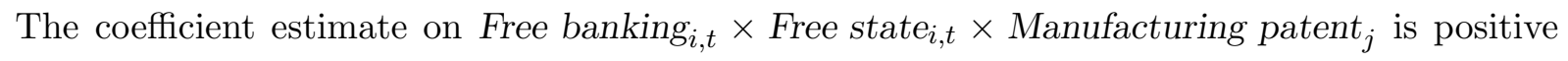
and significant. Again, this confirms that the impact of access to finance on innovation was most pronounced where labor was most scarce.

Panel B imposes the restriction that the states included should have agricultural output higher than manufacturing output. This restriction selects states where agriculture was the dominating industry. Once again, the results are qualitatively similar to those in Table 6. The coefficient estimates on Free banking $_{i, t}$ are still negative and significant, suggesting that the negative impact of free banking laws on agricultural innovation in slave states prevails. While the coefficient estimates on Free banking $_{i, t} \times$ Free state $_{i, t} \times$ Manufacturing patent $_{j}$ become insignificant because there are fewer observations, they remain economically sizable.

\section{Extensions and Robustness}

\subsection{Free banking and Access to Finance}

Earlier in the historical background, we have argued that the passage of the free banking laws accelerated bank entry, expanded the customer base of banks, and encouraged small businesses. In this section, we document the direct impact of free banking on access to finance. We hypothesize that passage of free banking laws increased access to finance and therefore encouraged innovation by increasing the credit supply needed to conduct innovation.

We estimate the following model:

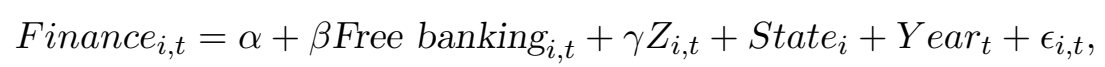

where Finance $_{i, t}$ is a measure of access to finance at state $i$ in year $t$. We use the counts of free banks, the ratio of free bank counts to total bank counts, the amount of loans issued by free banks, and the ratio of loan amounts from free banks to loan amounts from all banks. Table 9 reports the results estimating Eq. (9). As shown in the table, there was a significant increase 
in free bank counts and loans, in both the magnitude and the ratio. The economic magnitude is also sizable. The passage of the free banking laws led to a $10.4(=1.129 \times 3.04)$ increase of free bank counts and a $\$ 9(=6.915 \times 1.3)$ million increase of free bank loans in the third year following the passage. The increase in the free bank counts accounted for $53.4 \%(=10.4 / 19.49)$ of the state-level free bank count variability, and the increase in the free bank loans accounted for $69.2 \%$ (=9 million/13 million) of the state-level free bank loan variability. The evidence is consistent with the hypothesis that the passage of free banking laws improved access to finance.

\subsection{Free Banking in the Slave States}

We have shown that free banking contributed in reshaping the direction of innovation in the slave states, owing to the relative abundance of slave labor in agriculture and the relative scarcity of labor in manufacturing. However, historical research also pointed out that the southern banks functioned quite differently compared with banks in the North (e.g. Calomiris and Schweikart, 1991; Schweikart, 1987). ${ }^{23}$ Admittedly, due to the pre-existing branch bank networks serving plantation owners, entry of free banks was quite limited in the Southern states. Among all the southern states that passed the law, free banking was most active in Louisiana.

To mitigate the concern about limited free banking in the South, we next conduct tests by focusing on only slave states. We examine the impact of free banking on access to finance in the slave states by estimating Eq. (9), and the impact of free banking on innovation in the slave states by estimating Eq. (5). The estimation results are shown in Table 10. The effect of free banking on bank counts, bank loans, and innovation remains statistically and economically significant. We argue that, while the number of free bank entry might be endogenous to other state-level factors for example the existing banking system, the specific passage year of the law captured well exogenous changes in access to finance.

\section{Conclusion}

In this paper, we establish labor scarcity as a novel and important economic channel for the finance-growth nexus. We take a historical approach and examine antebellum America from 1812 to 1860 . This period witnessed the staggered passage of free banking laws across eighteen

\footnotetext{
${ }^{23}$ Southern banks refer to banks in the southern states, i.e. the slave states in our context.
} 
states, which provides us with a unique setting to identify banking shocks. Furthermore, the sharp contrast in labor scarcity between slave and free states makes antebellum America a perfect setting in which to examine the labor scarcity channel.

We confirm that access to finance, as identified by the staggered passage of the free banking laws, spurred innovation. However, improved access to finance alone was not sufficient to encourage innovation; importantly, the finance-growth nexus is more pronounced when one factor of production - i.e., labor - was scarce. Slavery in the South led to a low marginal cost of slave labor, which discouraged technological innovation that aimed to substitute for slave labor. Our research sheds new light on the factors that drive innovation. 


\section{Appendix}

\section{A List of States}

\begin{tabular}{|c|c|c|}
\hline State & Being a Slave or Free State & Year of Territory/Statehood \\
\hline Alabama & Slave State & 1819 \\
\hline Arkansas & Slave State & 1819 \\
\hline California & Free State & 1850 \\
\hline Connecticut & Free State & 1788 \\
\hline District of Columbia & Slave State & 1790 \\
\hline Delaware & Slave State & 1787 \\
\hline Florida & Slave State & 1822 \\
\hline Georgia & Slave State & 1788 \\
\hline Iowa & Free State & 1838 \\
\hline Illinois & Free State & 1809 \\
\hline Indiana & Free State & 1800 \\
\hline Kansas & Free State & 1854 \\
\hline Kentucky & Slave State & 1792 \\
\hline Louisiana & Slave State & 1804 \\
\hline Massachusetts & Free State & 1788 \\
\hline Maryland & Slave State & 1788 \\
\hline Maine & Free State & 1788 \\
\hline Michigan & Free State & 1805 \\
\hline Minnesota & Free State & 1849 \\
\hline Missouri & Slave State & 1812 \\
\hline Mississippi & Slave State & 1798 \\
\hline North Carolina & Slave State & 1789 \\
\hline Nebraska & Free State & 1854 \\
\hline New Hampshire & Free State & 1788 \\
\hline New Jersey & Free State & 1787 \\
\hline New Mexico & Slave State & 1850 \\
\hline New York & Free State & 1788 \\
\hline Ohio & Free State & 1803 \\
\hline Oregon & Free State & 1848 \\
\hline Pennsylvania & Free State & 1787 \\
\hline Rhode Island & Free State & 1790 \\
\hline South Carolina & Slave State & 1788 \\
\hline Tennessee & Slave State & 1796 \\
\hline Texas & Slave State & 1846 \\
\hline Utah & Slave State & 1850 \\
\hline Virginia & Slave State & 1788 \\
\hline Vermont & Free State & 1791 \\
\hline Washington & Free State & 1853 \\
\hline Wisconsin & Free State & 1836 \\
\hline
\end{tabular}




\section{B Variable Definitions}

\begin{tabular}{ll}
\hline Variable & Definition \\
\hline $\begin{array}{l}\text { Innovation Measure } \\
\text { Ln(Patents) }\end{array}$ & $\begin{array}{l}\text { Natural logarithm of one plus a state's total number of patents } \\
\text { granted in a given year. }\end{array}$
\end{tabular}

Free Banking Event

Free banking

Before 1- $^{-}$

After $^{3^{+}}$

After $^{2}$

After $^{1}$

State Characteristics

Ln(Population)

Urban ratio

Slave ratio

White ratio

Free state

Manufacturing patent

Max rate

Political party

Daily average wage (with board)

Daily average wage (without board)

An indicator variable that takes the value of zero prior to the passage of free banking law.

A variable that takes the value of one all years up to and including one year prior to the free banking law and zero otherwise.

A variable that takes the value of one, in year three and beyond after free banking and zero otherwise.

A variable that takes the value of one, in year two after the passage of free banking law and zero otherwise.

A variable that takes the value of one, in the year following the passage of free banking law and zero otherwise.

Natural logarithm of total number of people that resided at a state in a given year.

Ratio of urban population to total population at a state in a given year.

Ratio of slave population to total population at a state in a given year.

Ratio of white population to total population at a state in a given year.

An indicator variable that takes the value of one if a state was a free state in a given year.

A variable that takes the value of one if the patent counts in a state restrict to the manufacturing industry and zero if the patent counts in a state restrict to the agricultural industry (see section 4.1 for details on industry classification of patents).

The maximum interest rate limit in a state imposed by usury laws. A variable that takes the value of one if the presiding party in a state was Whig party or Republican and zero otherwise.

Average daily wage with board at the state level weighted by the proportion of free labor in the state.

Average daily wage without board at the state level weighted by the proportion of free labor in the state. 


\section{References}

Acemoglu, Daron, 2002, Directed technical change, Review of Economic Studies 69, 781-809.

, 2010, When does labor scarcity encourage innovation?, Journal of Political Economy $118,1037-1078$.

Amore, Mario Daniele, Cdric Schneider, and Alminas Zaldokas, 2013, Credit supply and corporate innovations, Journal of Financial Economics 109, 835-855.

Atack, Jeremy, Matthew Jaremski, and Peter L. Rousseau, 2014, American banking and the transportation revolution before the civil war, The Journal of Economic History 74, 943986.

Beck, Thorsten, Ross Levine, and Norman Loayza, 2000, Finance and the sources of growth, Journal of Financial Economics 58, 261 - 300 Special Issue on International Corporate Governance.

Bena, Jan, and Elena Simintzi, 2017, Globalization of work and innovation: Evidence from doing business in china, Discussion paper, .

Bencivenga, Valerie R., and Bruce D. Smith, 1991, Financial intermediation and endogenous growth, The Review of Economic Studies 58, 195-209.

Benmelech, Efraim, and Tobias J. Moskowitz, 2010, The political economy of financial regulation: Evidence from u.s. state usury laws in the19th century, Journal of Finance 65, 1029-1073.

Bertrand, Marianne, and Sendhil Mullainathan, 2003, Enjoying the quiet life? corporate governance and managerial preferences, Journal of Political Economy 111, 1043-1075.

Black, Sandra E., and Philip E. Strahan, 2002, Entrepreneurship and bank credit availability, The Journal of Finance 57, 2807-2833.

Bodenhorn, Howard, 2006, Bank chartering and political corruption in antebellum new york: Free banking as reform, in Edward L. Glaeser, and Claudia Goldin, ed.: In Corruption and Reform: Lessons from America's Economic History . pp. 231-257 (University of Chicago Press).

Brown, James R., Steven M. Fazzari, and Bruce C. Petersen, 2009, Financing Innovation and Growth: Cash Flow, External Equity, and the 1990s R\&D Boom, Journal of Finance 64, $151-185$.

Calomiris, Charles, and Larry Schweikart, 1991, The panic of 1857: Origins, transmission, and containment, The Journal of Economic History 51, 807-834.

Chava, Sudheer, Alexander Oettl, Ajay Subramanian, and Krishnamurthy V. Subramanian, 2013, Banking deregulation and innovation, Journal of Financial Economics 109, 759-774.

Chetty, Raj, Adam Looney, and Kory Kroft, 2009, Salience and taxation: Theory and evidence, American economic review 99, 1145-77.

Collins, W.H., 1904, The Domestic Slave Trade of the Southern States (New York).

Congress, 1837, House Documents, Otherwise Publ. as Executive Documents: 13th Congress, $2 d$ Session-49th Congress, 1st Session, Volume 2 (Congress).

Conrad, Alfred H., and John R. Meyer, 1958, The economics of slavery in the ante bellum south, Journal of Political Economy 66, 95-130. 
Cornaggia, Jess, Yifei Mao, Xuan Tian, and Brian Wolfe, 2015, Does banking competition affect innovation?, Journal of Financial Economics 115, 95-130.

Depuydt, Peter, 2013, The mortgaging of souls: Sugar, slaves, and speculation, Louisiana History: The Journal of the Louisiana Historical Association 54, 448-464.

Fogel, Robert W., and Stanley L. Engerman, 1974, Time on the Cross: The Economics of American Negro Slavery (Little, Brown and Company).

Fogel, Robert W.and Engerman, Stanley L., 1977, Explaining the relative efficiency of slave agriculture in the antebellum south, American Economic Review 67, 275-296.

Gonzalez, Felipe, Guillermo Marshall, and Suresh Naidu, 2017, Start-up nation? slave wealth and entrepreneurship in civil war maryland, The Journal of Economic History 77, 373405.

Greenwood, Jeremy, and Boyan Jovanovic, 1990, Financial development, growth, and the distribution of income, Journal of Political Economy 98, 1076-1107.

Griliches, Zvi, 1990, Patent statistics as economic indicators: A survey, Journal of Economic Literature 28, 1661-1707.

Gruber, Jonathan, 1994, The incidence of mandated maternity benefits, The American economic review pp. $622-641$.

Habakkuk, H.J., 1962, American and British Technology in the Nineteenth Century: The Search for Labour Saving Inventions (Cambridge University Press).

Hall, B. H., and M. Jaffe, A. B.and Trajtenberg, 2001, The nber u.s. patent citations data file: Lessons, insights, and methodological tools, Working Paper 8498 NBER.

Hall, Bronwyn H.and Lerner, Josh, 2010, The financing of r\&d and innovation, in Nathan Hall, Bronwyn H.and Rosenberg, ed.: Handbook of the Economics of Innovationvol. 1 . pp. 609-639 (North Holland).

Hammond, B, 1957, Banks and Politics in America: From the Revolution to the Civil War (Princeton University Press).

Hanlon, W. Walker, 2015, Necessity is the mother of invention: Input supplies and directed technical change, Econometrica 83, 67-100.

Hicks, J. R., 1932, The Theory of Wages (Macmillan).

Higgs, Robert, 1971, American inventiveness, 1870-1920, Journal of Political Economy 79, 661667.

Holmes, George K., 1892, Usury in law, in practice and in psychology, Political Science Quarterly 7, 431-467.

Hombert, Johan, and Adrien Matray, 2016, The real effects of lending relationships on innovative firms and inventor mobility, Review of Financial Studies 30, 2413-2445.

Hornbeck, Richard, and Suresh Naidu, 2014, When the levee breaks: Black migration and economic development in the american south, American Economic Review 104, 963-990.

Hsu, Po-Hsuan, Xuan Tian, and Yan Xu, 2014, Financial development and innovation: Crosscountry evidence, Journal of Financial Economics 112, 116-35.

Jaremski, Matthew, 2010, Free bank failures: Risky bonds versus undiversified portfolios, Journal of Money, Credit and Banking 42, 1565-1587. 
- and Peter Rousseau, 2013, Banks, free banks, and u.s.economic growth, Economic Inquiry 51, 1603-1621.

Jayaratne, Jith, and Philip E. Strahan, 1996, The finance-growth nexus: Evidence from bank branch deregulation, The Quarterly Journal of Economics 111, 639-670.

Kerr, William R., and Ramana Nanda, 2009, Democratizing entry: Banking deregulations, financing constraints, and entrepreneurship, Journal of Financial Economics 94, 124-149.

— 2015, Financing innovation, Annual Review of Financial Economics 7, 445-462.

King, Robert G., and Ross Levine, 1993, Finance and growth: Schumpeter might be right, Quarterly Journal of Economics 108, 717-737.

Lamoreaux, Naomi R., 1986, Banks, kinship, and economic development: The new england case, The Journal of Economic History 46, 647-667.

_, 1996, Insider Lending: Banks, Personal Connections, and Economic Development in Industrial New England (New York: National Bureau of Economic Research/Cambridge University Press).

, and Kenneth L. Sokoloff, 2000, The geography of invention in the american glass industry, 1870-1925, Journal of Economic History 60, 700-729.

Levine, Ross, 1997, Financial development and economic growth: Views and agenda, Journal of Economic Literature 35, 688-726.

Littlefield, Daniel C., 1991, Rice and Slaves: Ethnicity and the Slave Trade in Colonial South Carolina (University of Illinois Press).

Martin, Bonnie, 2010, Slavery's invisible engine: Mortgaging human property, The Journal of Southern History 76, 817-866.

Miller, Donald L., 1997, City of the Century: The Epic of Chicago and the Making of America (Simon \& Schuster).

Mitchener, Kris James, and Matthew Jaremski, 2015, The evolution of bank supervisory institutions: Evidence from american states, The Journal of Economic History 75, 819859.

Mokyr, Joel, 2010, Chapter 2 - the contribution of economic history to the study of innovation and technical change: 17501914, in Bronwyn H. Hall, and Nathan Rosenberg, ed.: Handbook of The Economics of Innovation, Vol. 1 vol. 1 of Handbook of the Economics of Innovation . pp. $11-50$ (North-Holland).

Murphy, S.A., 2017, Other People's Money: How Banking Worked in the Early American Republic. How Things Worked (Johns Hopkins University Press).

Porter, Michael E., 1992, Capital disadvantage: America's failing capital investment system, Harvard Business Review 70, 65-82.

Rockoff, Hugh, 1972, American free banking before the civil war: A re-examination, Journal of Economic History 32, 417-420.

$$
6,141-167 \text {. }
$$

Rolnick, Arthur J., and Warren E. Weber, 1985, Banking instability and regulation in the U.S. free banking era, Quarterly Review 9, 1-9. 
Rolnick, Arthur J.and Weber, Warren E., 1983, New evidence on the free banking era, American Economic Review 73, 1080-1091.

Rosenberg, Nathan, 1969, The direction of technological change: Inducement mechanisms and focusing devices, Economic Development and Cultural Change 18, 1-24.

Schaller, R. R., 1997, Moore's law: past, present and future, IEEE Spectrum 34, 52-59.

Schweikart, Larry, 1987, Southern banks and economic growth in the antebellum period: A reassessment, The Journal of Southern History 53, 19-36.

Sokoloff, Kenneth L., 1992, Invention, innovation, and manufacturing productivity growth in the antebellum northeast, in John Joseph Gallman, Robert E.and Wallis, ed.: American Economic Growth and Standards of Living before the Civil War . pp. 345-384 (University of Chicago Press).

, and B. Zorina Khan, 1990, The democratization of invention during early industrialization: Evidence from the united states, 1790-1846, The Journal of Economic History 50, $363-378$.

Solow, Robert M., 1957, Technical change and the aggregate production function, The Review of Economic Statistics 39, 312-320.

Spence, Michael, 1984, Cost reduction, competition, and industry performance, Econometrica $52,101-121$.

Stone, Alfred Holt, 1915, The cotton factorage system of the southern states, The American Historical Review 20, 557-565.

Thomson, Ross, 2004, From the old to the new: The social basis of innovation in the antebellum united states, Business and Economic History 2.

Wagner, Margaret E., Gary W. Gallagher, and Paul Finkelman, 2009, The Library of Congress Civil War Desk Reference (Simon \& Schuster).

Weber, Warren E., 2006, Early state banks in the united states: How many were there and when did they exist?, The Journal of Economic History 66, 433-455.

— , 2008, Balance sheets for u.s. antebellum state banks, Discussion paper, Research Department, Federal Reserve Bank of Minneapolis. 


\section{Table 1}

Summary statistics.

This table gives an overview of this paper's sample. Panel A reports summary statistics for the state-year observations, including dependent, independent, and control variables. Panel B reports the passage year of free banking laws in each affected state. Definitions of the variables are in Appendix B.

Panel A: Summary statistics

\begin{tabular}{lcccccc}
\hline & P25 & P50 & Mean & P75 & SD & N \\
\hline Patents & 1 & 5 & 25.14 & 18 & 75.40 & 1,491 \\
Patents (agricultural) & 0 & 0 & 2.27 & 2 & 7.2 & 1,491 \\
Patents (manufacturing) & 0 & 1 & 10.19 & 6 & 35.03 & 1,491 \\
Population (thousands) & 270 & 780 & 1,100 & 1,400 & 1,200 & 1,491 \\
Urban ratio & 0.02 & 0.05 & 0.12 & 0.16 & 0.18 & 1,491 \\
Slave ratio & 0 & 0 & 0.15 & 0.31 & 0.19 & 1,491 \\
White ratio & 0.65 & 0.93 & 0.82 & 0.99 & 0.19 & 1,491 \\
Political party & 0 & 0 & 0.38 & 1 & 0.48 & 868 \\
Max rate & 0.06 & 0.06 & 0.08 & 0.08 & 0.07 & 1,419 \\
Free bank counts & 0 & 0 & 3.04 & 0 & 19.49 & 1,491 \\
Free ratio & 0 & 0 & 0.03 & 0 & 0.14 & 1,491 \\
Free bank loans (thousands) & 0 & 0 & 1,300 & 0 & 13,000 & 1,491 \\
Free bank loan ratio & 0 & 0 & 0.03 & 0 & 0.15 & 1,491 \\
\hline
\end{tabular}


Panel B: Passage of free banking laws

\begin{tabular}{ll}
\hline State & Year of passage \\
\hline Michigan* & 1837,1857 \\
New York & 1838 \\
Georgia & 1838 \\
Alabama & 1849 \\
New Jersey & 1850 \\
Vermont & 1851 \\
Ohio & 1851 \\
Massachusetts & 1851 \\
Illinois & 1851 \\
Connecticut & 1852 \\
Indiana & 1852 \\
Wisconsin & 1852 \\
Tennessee & 1852 \\
Louisiana & 1853 \\
Florida & 1853 \\
Minnesota & 1858 \\
Iowa & 1858 \\
Pennsylvania & 1860 \\
\hline
\end{tabular}

*Michigan passed the free banking law in 1837 , then abolished in 1840 , and later reinstated in 1857. 


\section{Table 2}

Baseline regressions.

This table reports OLS regression estimates of Eq. (5). The dependent variable in columns $1-2,3-4$, and 5-6 is the natural logarithm of one plus the sum of the patents granted in a state in year $t+1, t+2$, and $t+3$, respectively. Definitions of variables are in Appendix B. Robust standard errors clustered at the year level are reported in parentheses. ${ }^{* * *},{ }^{* *}$, and $*$ indicate significance at the $1 \%, 5 \%$, and $10 \%$ levels, respectively.

\begin{tabular}{lcccccc}
\hline & \multicolumn{5}{c}{ Ln(Patents) } \\
\cline { 2 - 7 } & \multicolumn{2}{c}{$\mathrm{t}+1$} & \multicolumn{2}{c}{$\mathrm{t}+2$} & \multicolumn{2}{c}{$\mathrm{t}+3$} \\
\cline { 2 - 7 } & $(1)$ & $(2)$ & $(3)$ & $(4)$ & $(5)$ & $(6)$ \\
\hline \multirow{2}{*}{ Free banking } & $0.440^{* * *}$ & $0.385^{* * *}$ & $0.518^{* * *}$ & $0.456^{* * *}$ & $0.531^{* * *}$ & $0.463^{* * *}$ \\
Ln(Population) & $(0.081)$ & $(0.064)$ & $(0.104)$ & $(0.081)$ & $(0.111)$ & $(0.085)$ \\
& & $0.452^{* * *}$ & & $0.517^{* * *}$ & & $0.587^{* * *}$ \\
Urban ratio & & $(0.044)$ & & $(0.055)$ & & $(0.063)$ \\
& & $1.493^{* * *}$ & & $2.239^{* * *}$ & & $2.877^{* * *}$ \\
Slave ratio & & $(0.482)$ & & $(0.815)$ & & $(0.906)$ \\
& & $-2.924^{*}$ & & $-4.504^{* *}$ & & $-5.955^{* * *}$ \\
White ratio & & $(1.499)$ & & $(1.911)$ & & $(2.180)$ \\
Constant & & -0.944 & & -2.154 & & -3.022 \\
& 0.033 & $-3.925^{* * *}$ & 0.084 & $-3.321^{* *}$ & -0.070 & $-3.834)$ \\
Observations & $(0.089)$ & $(1.180)$ & $(0.098)$ & $(1.344)$ & $(0.107)$ & $(1.404)$ \\
R-squared & & & & & & \\
State FE & 1,491 & 1,491 & 1,491 & 1,491 & 1,491 & 1,491 \\
Year FE & 0.878 & 0.893 & 0.868 & 0.889 & 0.861 & 0.888 \\
& Yes & Yes & Yes & Yes & Yes & Yes \\
& Yes & Yes & Yes & Yes & Yes & Yes \\
\hline
\end{tabular}




\section{Table 3}

Additional endogeneity tests.

This table reports robustness tests of the baseline regressions. Panel A reports OLS regression estimates of Eq. (6) with Michigan state excluded. Since Michigan abolished the free banking law once and reinstated later, the dynamic effects of the free banking laws on innovation might be different from other states. Dependent variables in columns 1-2 are the natural logarithm of one plus the sum of the patents granted in year $t+1$. Panel B reports OLS regression estimates of Eq. (5) with randomized free banking passage across states. Dependent variables in columns 1-3 are the natural logarithm of one plus the sum of the patents granted in year $t+1, t+2$, and $\mathrm{t}+3$, respectively. Panel $\mathrm{C}$ reports OLS regression estimates of Eq. (5) with additional controls. Columns 1-3 have Max rate as the additional control variable. Dependent variables in columns 1-3 are the natural logarithm of one plus the sum of the patents granted in year $\mathrm{t}+1, \mathrm{t}+2$, and $\mathrm{t}+3$, respectively. Columns $4-6$ have Political party as the additional control variable. Dependent variables in columns 4-6 are the natural logarithm of one plus the sum of the patents granted in year $t+1, t+2$, and $t+3$, respectively. Robust standard errors clustered at the year level are reported in parentheses. $* * *, * *$, and * indicate significance at the $1 \%$, $5 \%$, and $10 \%$ levels, respectively. Definitions of variables are in Appendix B.

Panel A: Dynamic effects of free banking on innovation

\begin{tabular}{lcc}
\hline & \multicolumn{2}{c}{ Ln(Patents) } \\
\cline { 2 - 3 } & $(1)$ & $(2)$ \\
\hline Before $^{1-}$ & -0.207 & -0.082 \\
After $^{1}$ & $(0.172)$ & $(0.149)$ \\
& $0.283^{* * *}$ & $0.273^{* *}$ \\
After $^{2}$ & $(0.104)$ & $(0.106)$ \\
& $0.230^{*}$ & $0.226^{*}$ \\
After $^{3+}$ & $(0.138)$ & $(0.137)$ \\
& $0.310^{* * *}$ & $0.405^{* * *}$ \\
Ln$^{*}$ Population $)$ & $(0.153)$ & $(0.137)$ \\
& & $0.512^{* * *}$ \\
Urban ratio & & $(0.102)$ \\
& & $1.374^{*}$ \\
Slave ratio & & $(0.799)$ \\
& & -1.709 \\
White ratio & & $(4.031)$ \\
& & -0.991 \\
Constant & 0.239 & $(4.487)$ \\
Observations & $(0.187)$ & $(3.857)$ \\
R-squared & 1,442 & 1,442 \\
State FE & 0.880 & 0.895 \\
Year FE & Yes & Yes \\
\hline
\end{tabular}


Panel B: Randomization of free banking

\begin{tabular}{lccc}
\hline & \multicolumn{3}{c}{$\operatorname{Ln}($ Patents $)$} \\
\cline { 2 - 4 } & $\mathrm{t}+1$ & $\mathrm{t}+2$ & $\mathrm{t}+3$ \\
\cline { 2 - 4 } & $(1)$ & $(2)$ & $(3)$ \\
\hline Free banking & 0.061 & 0.004 & 0.006 \\
& $(0.060)$ & $(0.057)$ & $(0.057)$ \\
Ln(Population) & $0.467^{* * *}$ & $0.531^{* * *}$ & $0.600^{* * *}$ \\
& $(0.047)$ & $(0.059)$ & $(0.070)$ \\
Urban ratio & $1.646^{* * *}$ & $2.451^{* * *}$ & $3.091^{* * *}$ \\
& $(0.519)$ & $(0.878)$ & $(0.971)$ \\
Slave ratio & -1.892 & $-3.180^{*}$ & $-4.612^{* *}$ \\
& $(1.377)$ & $(1.748)$ & $(2.042)$ \\
White ratio & -0.163 & -1.203 & -2.056 \\
Constant & $(1.353)$ & $(1.693)$ & $(1.814)$ \\
& $-4.934^{* * *}$ & $-4.514^{* * *}$ & $-4.446^{* * *}$ \\
Observations & $(1.132)$ & $(1.269)$ & $(1.326)$ \\
R-squared & 1,491 & 1,491 & 1,491 \\
State FE & 0.890 & 0.885 & 0.883 \\
Year FE & Yes & Yes & Yes \\
\hline
\end{tabular}


Panel C: Are other factors driving the results?

\begin{tabular}{|c|c|c|c|c|c|c|}
\hline & & & $\operatorname{Ln}(\mathrm{H}$ & atents) & & \\
\hline & $\mathrm{t}+1$ & $\mathrm{t}+2$ & $\mathrm{t}+3$ & $\mathrm{t}+1$ & $\mathrm{t}+2$ & $\mathrm{t}+3$ \\
\hline & $(1)$ & $(2)$ & $(3)$ & $(4)$ & $(5)$ & $(6)$ \\
\hline Free banking & $\begin{array}{c}0.368^{* * *} \\
(0.067)\end{array}$ & $\begin{array}{c}0.431^{* * *} \\
(0.083)\end{array}$ & $\begin{array}{c}0.441^{* * *} \\
(0.087)\end{array}$ & $\begin{array}{c}0.228^{* * *} \\
(0.056)\end{array}$ & $\begin{array}{c}0.327^{* * *} \\
(0.086)\end{array}$ & $\begin{array}{c}0.350^{* * *} \\
(0.095)\end{array}$ \\
\hline Max rate & $\begin{array}{c}0.397 \\
(0.249)\end{array}$ & $\begin{array}{c}0.016 \\
(0.498)\end{array}$ & $\begin{array}{l}-0.152 \\
(0.324)\end{array}$ & & & \\
\hline Political party & & & & $\begin{array}{c}0.022 \\
(0.051)\end{array}$ & $\begin{array}{c}0.082 \\
(0.061)\end{array}$ & $\begin{array}{c}0.126^{* *} \\
(0.058)\end{array}$ \\
\hline Ln(Population) & $\begin{array}{c}0.593^{* * *} \\
(0.051)\end{array}$ & $\begin{array}{c}0.652^{* * *} \\
(0.062)\end{array}$ & $\begin{array}{c}0.732^{* * *} \\
(0.069)\end{array}$ & $\begin{array}{c}0.503^{* * *} \\
(0.108)\end{array}$ & $\begin{array}{c}0.559^{* * *} \\
(0.103)\end{array}$ & $\begin{array}{c}0.618^{* * *} \\
(0.115)\end{array}$ \\
\hline Urban ratio & $\begin{array}{c}1.905^{* * *} \\
(0.498)\end{array}$ & $\begin{array}{c}2.654^{* * *} \\
(0.848)\end{array}$ & $\begin{array}{c}3.202^{* * *} \\
(0.917)\end{array}$ & $\begin{array}{c}1.343 \\
(0.840)\end{array}$ & $\begin{array}{l}2.689^{*} \\
(1.335)\end{array}$ & $\begin{array}{c}3.375^{* *} \\
(1.489)\end{array}$ \\
\hline Slave ratio & $\begin{array}{c}-4.767^{* *} \\
(1.832)\end{array}$ & $\begin{array}{c}-5.719^{* *} \\
(2.144)\end{array}$ & $\begin{array}{c}-6.272^{* * *} \\
(2.054)\end{array}$ & $\begin{array}{c}-5.402^{* *} \\
(2.605)\end{array}$ & $\begin{array}{c}-9.074^{* *} \\
(3.317)\end{array}$ & $\begin{array}{c}-12.687^{* * *} \\
(3.869)\end{array}$ \\
\hline White ratio & $\begin{array}{l}-2.469 \\
(1.837)\end{array}$ & $\begin{array}{l}-2.957 \\
(2.043)\end{array}$ & $\begin{array}{l}-2.642 \\
(1.737)\end{array}$ & $\begin{array}{c}-5.110^{* *} \\
(2.097)\end{array}$ & $\begin{array}{c}-7.805^{* * *} \\
(2.471)\end{array}$ & $\begin{array}{c}-9.832^{* * *} \\
(2.231)\end{array}$ \\
\hline Constant & $\begin{array}{c}-4.129^{* *} \\
(1.648)\end{array}$ & $\begin{array}{c}-4.070^{* *} \\
(1.708)\end{array}$ & $\begin{array}{c}-5.253^{* * *} \\
(1.492)\end{array}$ & $\begin{array}{l}-0.242 \\
(2.792)\end{array}$ & $\begin{array}{c}1.995 \\
(2.739)\end{array}$ & $\begin{array}{c}3.521 \\
(2.133)\end{array}$ \\
\hline Observations & 1,419 & 1,419 & 1,419 & 868 & 868 & 868 \\
\hline R-squared & 0.897 & 0.891 & 0.888 & 0.918 & 0.913 & 0.912 \\
\hline State FE & Yes & Yes & Yes & Yes & Yes & Yes \\
\hline Year FE & Yes & Yes & Yes & Yes & Yes & Yes \\
\hline
\end{tabular}




\section{Table 4}

Differences in labor conditions: Slave states vs. free states.

This table presents summary statistics for labor in slave states and free states. Definitions of variables are in Appendix B.

\begin{tabular}{lcccccc}
\hline & P25 & P50 & Mean & P75 & SD & N \\
\hline & Free states & & & & \\
Population (thousands) & 420 & 650 & 1,300 & 1,500 & 1,400 & 743 \\
Urban ratio & 0.030 & 0.09 & 0.13 & 0.17 & 0.14 & 743 \\
Slave ratio & 0 & 0 & 0 & 0 & 0 & 743 \\
White ratio & 0.97 & 0.99 & 0.98 & 1 & 0.02 & 743 \\
Daily average wage (with board) & 0.62 & 0.69 & 0.78 & 0.76 & 0.46 & 743 \\
Daily average wage (without board) & 0.85 & 0.94 & 1.05 & 1 & 0.58 & 743 \\
\hline \multicolumn{7}{c}{ Slave states } \\
Population (thousands) & 190 & 900 & 950 & 1,400 & 740 & 748 \\
Urban ratio & 0.01 & 0.04 & 0.12 & 0.11 & 0.22 & 748 \\
Slave ratio & 0.18 & 0.31 & 0.3 & 0.44 & 0.16 & 748 \\
White ratio & 0.55 & 0.65 & 0.66 & 0.76 & 0.14 & 748 \\
Daily average wage (with board) & 0.3 & 0.38 & 0.4 & 0.47 & 0.15 & 748 \\
Daily average wage (without board) & 0.43 & 0.54 & 0.57 & 0.64 & 0.23 & 748 \\
\hline
\end{tabular}




\section{Table 5}

Labor scarcity and innovation.

This table presents regression coefficient estimates of Eq. (7). Dependent variables in columns 1-3 are the natural logarithm of one plus the sum of the patents granted in year $t+1, t+2$, and $t+3$, respectively. Robust standard errors clustered at the year level are reported in parentheses. ${ }^{* * *},{ }^{* *}$, and $*$ indicate significance at the $1 \%, 5 \%$, and $10 \%$ levels, respectively. Definitions of variables are in Appendix B.

\begin{tabular}{lccc}
\hline & \multicolumn{3}{c}{ Ln(Patents) } \\
\cline { 2 - 4 } & $\mathrm{t}+1$ & $\mathrm{t}+2$ & $\mathrm{t}+3$ \\
\cline { 2 - 4 } & $(1)$ & $(2)$ & $(3)$ \\
\hline Free banking $\times$ Free state & $0.442^{* * *}$ & $0.469^{* * *}$ & $0.558^{* * *}$ \\
& $(0.084)$ & $(0.148)$ & $(0.172)$ \\
Free banking & 0.092 & 0.146 & 0.094 \\
& $(0.090)$ & $(0.087)$ & $(0.095)$ \\
Free state & $-1.509^{* * *}$ & $-1.215^{* *}$ & $-1.085^{* *}$ \\
& $(0.361)$ & $(0.503)$ & $(0.500)$ \\
Ln(Population) & $0.434^{* * *}$ & $0.498^{* * *}$ & $0.564^{* * *}$ \\
& $(0.043)$ & $(0.050)$ & $(0.057)$ \\
Urban ratio & $0.873^{*}$ & $1.581^{* *}$ & $2.093^{* * *}$ \\
Slave ratio & $(0.469)$ & $(0.670)$ & $(0.714)$ \\
White ratio & -2.124 & $-3.655^{* *}$ & $-4.945^{* *}$ \\
Constant & $(1.458)$ & $(1.723)$ & $(1.858)$ \\
& -0.154 & -1.315 & -2.024 \\
Observations & $(1.389)$ & $(1.612)$ & $(1.537)$ \\
R-squared & $-4.421^{* * *}$ & $-3.847^{* * *}$ & $-3.860^{* * *}$ \\
State FE & $(1.213)$ & $(1.315)$ & $(1.261)$ \\
Year FE & 1,491 & 1,491 & 1,491 \\
& 0.894 & 0.891 & 0.890 \\
& Yes & Yes & Yes \\
& Yes & Yes & Yes \\
\hline & & &
\end{tabular}




\section{Table 6}

Labor scarcity and innovation: Patent industry classification.

This table presents regression coefficient estimates of Eq. (8). Dependent variables in columns 1-3 are the natural logarithm of one plus the sum of the patents granted in year $t+1, t+2$, and $t+3$, respectively. Robust standard errors clustered at the year level are reported in parentheses. $* * *, * *$, and $*$ indicate significance at the $1 \%, 5 \%$, and $10 \%$ levels, respectively. Definitions of variables are in Appendix B.

\begin{tabular}{lccc}
\hline & \multicolumn{3}{c}{$\operatorname{Ln}($ Patents $)$} \\
\cline { 2 - 4 } & $\mathrm{t}+1$ & $\mathrm{t}+2$ & $\mathrm{t}+3$ \\
\cline { 2 - 4 } & $(1)$ & $(2)$ & $(3)$ \\
\hline Free banking & $-0.298^{* * *}$ & $-0.232^{* *}$ & $-0.244^{* *}$ \\
Free banking $\times$ Free state & $(0.100)$ & $(0.098)$ & $(0.094)$ \\
& $0.789^{* * *}$ & $0.831^{* * *}$ & $0.905^{* * *}$ \\
Free banking $\times$ Manufacturing patent & $(0.125)$ & $(0.138)$ & $(0.134)$ \\
& $0.248^{* *}$ & $0.220^{* *}$ & $0.249^{* *}$ \\
Free banking $\times$ Free state $\times$ Manufacturing patent & $(0.104)$ & $(0.108)$ & $(0.108)$ \\
Manufacturing patent $\times$ Free state & $0.345^{* *}$ & $0.355^{* * *}$ & $0.306^{* *}$ \\
Free state & $(0.129)$ & $(0.128)$ & $(0.115)$ \\
Manufacturing patent & $0.409^{* * *}$ & $0.428^{* * *}$ & $0.453^{* * *}$ \\
Constant & $(0.039)$ & $(0.040)$ & $(0.040)$ \\
Controls & $-2.675^{* * *}$ & $-2.526^{* * *}$ & $-2.336^{* * *}$ \\
Observations & $(0.192)$ & $(0.271)$ & $(0.278)$ \\
R-squared & $0.337^{* * *}$ & $0.352^{* * *}$ & $0.364^{* * *}$ \\
State FE & $(0.040)$ & $(0.040)$ & $(0.040)$ \\
Year FE & -0.048 & 0.611 & 0.757 \\
\hline
\end{tabular}




\section{Table 7}

Slave population.

This table presents OLS regression coefficient estimates of regressing Slave ratio on Free banking. Robust standard errors clustered at the year level are reported in parentheses. ***, $* *$, and $*$ indicate significance at the $1 \%, 5 \%$, and $10 \%$ levels, respectively. Definitions of variables are in Appendix B.

\begin{tabular}{lcc}
\hline & \multicolumn{2}{c}{ Slave ratio } \\
\cline { 2 - 3 } & $(1)$ & $(2)$ \\
\hline Free banking & $1.090^{*}$ & $0.751^{* *}$ \\
& $(0.470)$ & $(0.217)$ \\
Ln(Population) & & 0.273 \\
& & $(0.232)$ \\
Urban ratio & & -2.827 \\
& & $(2.660)$ \\
White ratio & & $-77.427^{* * *}$ \\
& & $(14.425)$ \\
Constant & $40.244^{* * *}$ & $82.519^{* * *}$ \\
& $(2.657)$ & $(6.977)$ \\
Observations & 160 & 160 \\
R-squared & 0.986 & 0.996 \\
State FE & Yes & Yes \\
Year FE & Yes & Yes \\
\hline
\end{tabular}




\section{Table 8}

Labor scarcity and innovation: Controlling for industry concentration.

This table presents OLS regression coefficient estimates. Panel A restricts the sample to states with more manufacturing output, i.e., states with more annual manufacturing output than annual agricultural output. Panel B restricts the sample to states with more agricultural output, i.e., states with more annual agricultural output than annual manufacturing output. Dependent variables in columns 1-3 are the natural logarithm of one plus the sum of the patents granted in year $\mathrm{t}+1, \mathrm{t}+2$, and $\mathrm{t}+3$, respectively. Robust standard errors clustered at the year level are reported in parentheses. $*^{* *}, * *$, and $*$ indicate significance at the $1 \%, 5 \%$, and $10 \%$ levels, respectively. Definitions of variables are in Appendix B.

Panel A: States with more manufacturing output

\begin{tabular}{lccc}
\hline & \multicolumn{3}{c}{$\operatorname{Ln}($ Patents $)$} \\
\cline { 2 - 4 } & $\mathrm{t}+1$ & $\mathrm{t}+2$ & $\mathrm{t}+3$ \\
\cline { 2 - 4 } & $(1)$ & $(2)$ & $(3)$ \\
\hline Free banking $\times$ Free state & $0.179^{* *}$ & $0.272^{* * *}$ & $0.260^{* * *}$ \\
Free banking $\times$ Free state $\times$ Manufacturing patent & $(0.085)$ & $(0.069)$ & $(0.067)$ \\
& $0.844^{* * *}$ & $0.781^{* * *}$ & $0.783^{* * *}$ \\
Manufacturing patent $\times$ Free state & $(0.099)$ & $(0.093)$ & $(0.101)$ \\
& $0.320^{* * *}$ & $0.350^{* * *}$ & $0.373^{* * *}$ \\
Free state & $(0.070)$ & $(0.071)$ & $(0.072)$ \\
& $2.550^{* * *}$ & $2.700^{* * *}$ & $2.789^{* * *}$ \\
Manufacturing patent & $(0.629)$ & $(0.685)$ & $(0.720)$ \\
& $0.668^{* * *}$ & $0.682^{* * *}$ & $0.696^{* * *}$ \\
Constant & $(0.080)$ & $(0.080)$ & $(0.079)$ \\
& $-17.251^{* * *}$ & $-16.430^{* * *}$ & $-17.068^{* * *}$ \\
Controls & $(4.034)$ & $(4.273)$ & $(4.068)$ \\
Observations & Yes & Yes & Yes \\
R-squared & 1,146 & 1,146 & 1,146 \\
State FE & 0.847 & 0.851 & 0.854 \\
Year FE & Yes & Yes & Yes \\
\hline
\end{tabular}


Panel B: States with more agricultural output

\begin{tabular}{lccc}
\hline & \multicolumn{3}{c}{$\operatorname{Ln}($ Patents $)$} \\
\cline { 2 - 4 } & $\mathrm{t}+1$ & $\mathrm{t}+2$ & $\mathrm{t}+3$ \\
\cline { 2 - 4 } & $(1)$ & $(2)$ & $(3)$ \\
\hline Free banking & $-0.340^{* * *}$ & $-0.242^{* *}$ & $-0.226^{* *}$ \\
Free banking $\times$ Free state & $(0.101)$ & $(0.102)$ & $(0.096)$ \\
& $0.814^{* * *}$ & $0.834^{* * *}$ & $0.966^{* * *}$ \\
Free banking $\times$ Manufacturing patent & $(0.118)$ & $(0.144)$ & $(0.147)$ \\
& $0.339^{* * *}$ & $0.310^{* * *}$ & $0.340^{* * *}$ \\
Free banking $\times$ Free state $\times$ Manufacturing patent & $(0.105)$ & $(0.108)$ & $(0.109)$ \\
Manufacturing patent $\times$ Free state & 0.149 & 0.205 & 0.135 \\
Free state & $(0.134)$ & $(0.143)$ & $(0.134)$ \\
Manufacturing patent & $0.153^{* * *}$ & $0.158^{* * *}$ & $0.184^{* * *}$ \\
Constant & $(0.038)$ & $(0.039)$ & $(0.039)$ \\
& $-2.801^{* * *}$ & $-2.615^{* * *}$ & $-2.429^{* * *}$ \\
Controls & $(0.192)$ & $(0.311)$ & $(0.347)$ \\
Observations & $0.246^{* * *}$ & $0.262^{* * *}$ & $0.273^{* * *}$ \\
R-squared & $(0.035)$ & $(0.035)$ & $(0.036)$ \\
State FE & 1.565 & 3.601 & $5.617^{* * *}$ \\
Year FE & $(2.095)$ & $(2.207)$ & $(2.045)$ \\
\hline
\end{tabular}




\section{Table 9}

Free banking and access to finance.

This table presents OLS regression coefficient estimates for Eq. (9). Panel A examines free banks. Dependent variables in columns 1-3 are the natural logarithm of one plus free bank counts at a state in year $\mathrm{t}+1, \mathrm{t}+2, \mathrm{t}+3$, respectively. Dependent variables in columns $4-6$ are the ratio of free bank counts and total bank counts at a state in year $t+1, t+2, t+3$. Panel $\mathrm{B}$ examines loans lent by free banks. Dependent variables in columns 1-3 are the natural logarithm of one plus free bank loans at a state in year $t+1, t+2$, and $t+3$, respectively. Dependent variables in columns 4-6 are the ratio of free bank loans and total bank loans at a state in year $t+1, t+2$, and $t+3$, respectively. Robust standard errors clustered at the year level are reported in parentheses. $* * *, * *$, and $*$ indicate significance at the $1 \%, 5 \%$, and $10 \%$ levels, respectively. Definitions of variables are in Appendix B.

Panel A: Free banks

\begin{tabular}{|c|c|c|c|c|c|c|}
\hline & \multicolumn{3}{|c|}{ Ln(Free bank counts $)$} & \multicolumn{3}{|c|}{ Free bank ratio } \\
\hline & $\mathrm{t}+1$ & $t+2$ & $t+3$ & $\mathrm{t}+1$ & $\mathrm{t}+2$ & $\mathrm{t}+3$ \\
\hline & (1) & $(2)$ & $(3)$ & (4) & $(5)$ & (6) \\
\hline Free banking & $\begin{array}{c}1.531^{* * *} \\
(0.144)\end{array}$ & $\begin{array}{c}1.326^{* * *} \\
(0.190)\end{array}$ & $\begin{array}{c}1.129^{* * *} \\
(0.216)\end{array}$ & $\begin{array}{c}0.232^{* * *} \\
(0.027)\end{array}$ & $\begin{array}{c}0.189^{* * *} \\
(0.033)\end{array}$ & $\begin{array}{c}0.151^{* * *} \\
(0.036)\end{array}$ \\
\hline Ln(Population) & $\begin{array}{c}0.126^{* * *} \\
(0.039)\end{array}$ & $\begin{array}{c}0.138^{* * *} \\
(0.045)\end{array}$ & $\begin{array}{c}0.145^{* * *} \\
(0.050)\end{array}$ & $\begin{array}{c}0.053^{* * *} \\
(0.012)\end{array}$ & $\begin{array}{c}0.054^{* * *} \\
(0.014)\end{array}$ & $\begin{array}{c}0.053^{* * *} \\
(0.015)\end{array}$ \\
\hline Urban ratio & $\begin{array}{c}3.312^{* * *} \\
(0.692)\end{array}$ & $\begin{array}{c}2.870^{* * *} \\
(0.799)\end{array}$ & $\begin{array}{c}2.408^{* * *} \\
(0.838)\end{array}$ & $\begin{array}{c}0.421^{* * *} \\
(0.086)\end{array}$ & $\begin{array}{c}0.381^{* * *} \\
(0.099)\end{array}$ & $\begin{array}{c}0.335^{* * *} \\
(0.105)\end{array}$ \\
\hline Slave ratio & $\begin{array}{c}-3.541^{* * * *} \\
(1.313)\end{array}$ & $\begin{array}{c}-3.897^{* * *} \\
(1.139)\end{array}$ & $\begin{array}{c}-3.924^{* * *} \\
(1.061)\end{array}$ & $\begin{array}{c}-0.959^{* * *} * \\
(0.286)\end{array}$ & $\begin{array}{c}-0.974^{* * *} \\
(0.248)\end{array}$ & $\begin{array}{c}-0.931^{* * *} \\
(0.229)\end{array}$ \\
\hline White ratio & $\begin{array}{c}-3.752^{* *} \\
(1.450)\end{array}$ & $\begin{array}{c}-4.059 * * * \\
(1.236)\end{array}$ & $\begin{array}{c}-3.982^{* * *} \\
(1.159)\end{array}$ & $\begin{array}{c}-0.836^{* * *} \\
(0.298)\end{array}$ & $\begin{array}{c}-0.877^{* * *} \\
(0.243)\end{array}$ & $\begin{array}{c}-0.844^{* * *} \\
(0.220)\end{array}$ \\
\hline Constant & $\begin{array}{c}1.832 \\
(1.145)\end{array}$ & $\begin{array}{c}2.022^{* *} \\
(0.959)\end{array}$ & $\begin{array}{c}1.904^{* *} \\
(0.830)\end{array}$ & $\begin{array}{c}0.184 \\
(0.225)\end{array}$ & $\begin{array}{c}0.217 \\
(0.182)\end{array}$ & $\begin{array}{c}0.193 \\
(0.150)\end{array}$ \\
\hline Observations & 1,491 & 1,491 & 1,491 & 1,491 & 1,491 & 1,491 \\
\hline R-squared & 0.626 & 0.573 & 0.530 & 0.537 & 0.484 & 0.444 \\
\hline State FE & Yes & Yes & Yes & Yes & Yes & Yes \\
\hline Year FE & Yes & Yes & Yes & Yes & Yes & Yes \\
\hline Cluster by Year & Yes & Yes & Yes & Yes & Yes & Yes \\
\hline
\end{tabular}


Panel B: Free bank loans

\begin{tabular}{lcccccc}
\hline & \multicolumn{3}{c}{$\operatorname{Ln}($ Free bank loans) } & \multicolumn{3}{c}{ Free bank loan ratio } \\
\cline { 2 - 7 } & $\mathrm{t}+1$ & $\mathrm{t}+2$ & $\mathrm{t}+3$ & $\mathrm{t}+1$ & $\mathrm{t}+2$ & $\mathrm{t}+3$ \\
\cline { 2 - 7 } Free banking & $(1)$ & $(2)$ & $(3)$ & $(4)$ & $(5)$ & $(6)$ \\
& $7.486^{* * *}$ & $7.229^{* * *}$ & $6.915^{* * *}$ & $0.187^{* * *}$ & $0.176^{* * *}$ & $0.160^{* * *}$ \\
Ln(Population) & $(0.613)$ & $(0.590)$ & $(0.770)$ & $(0.015)$ & $(0.018)$ & $(0.028)$ \\
& $0.510^{* * *}$ & $0.651^{* * *}$ & $0.825^{* * *}$ & $0.073^{* * *}$ & $0.078^{* * *}$ & $0.084^{* * *}$ \\
Urban ratio & $(0.148)$ & $(0.161)$ & $(0.175)$ & $(0.009)$ & $(0.010)$ & $(0.011)$ \\
& $13.088^{* * *}$ & $13.477^{* * *}$ & $14.133^{* * *}$ & $0.430^{* * *}$ & $0.453^{* * *}$ & $0.484^{* * *}$ \\
Slave ratio & $(3.402)$ & $(3.683)$ & $(3.824)$ & $(0.079)$ & $(0.083)$ & $(0.079)$ \\
& -9.392 & -12.445 & $-15.819^{* *}$ & $-0.692^{* * *}$ & $-0.779^{* * *}$ & $-0.879^{* * *}$ \\
White ratio & $(7.522)$ & $(7.533)$ & $(7.072)$ & $(0.231)$ & $(0.235)$ & $(0.230)$ \\
Constant & -13.925 & $-18.122^{*}$ & $-22.842^{* *}$ & -0.308 & -0.407 & $-0.527^{* *}$ \\
Observations & $(10.247)$ & $(10.280)$ & $(9.081)$ & $(0.265)$ & $(0.277)$ & $(0.252)$ \\
R-squared & 5.796 & 7.837 & 9.924 & $-0.509^{* *}$ & $-0.479^{*}$ & $-0.441^{*}$ \\
State FE & $(9.494)$ & $(9.338)$ & $(8.262)$ & $(0.226)$ & $(0.250)$ & $(0.236)$ \\
Year FE & 1,452 & 1,413 & 1,374 & 1,452 & 1,413 & 1,374 \\
\hline
\end{tabular}




\section{Table 10}

Free banking in the slave states.

This table presents OLS regression coefficient estimates for Eq. (9) with only slave states. Panel A examines free banks. Dependent variables in columns 1-3 are the natural logarithm of one plus free bank counts at a state in year $t+1, t+2, t+3$, respectively. Dependent variables in columns 4-6 are the ratio of free bank counts and total bank counts at a state in year $t+1, t+2$, $t+3$. Panel B examines loans lent by free banks. Dependent variables in columns $1-3$ are the natural logarithm of one plus free bank loans at a state in year $t+1, t+2$, and $t+3$, respectively. Dependent variables in columns $4-6$ are the ratio of free bank loans and total bank loans at a state in year $\mathrm{t}+1, \mathrm{t}+2$, and $\mathrm{t}+3$, respectively. Panel $\mathrm{C}$ examines innovation. The dependent variable in columns 1,2 , and 3 is the natural logarithm of one plus the sum of the patents granted in a state in year $t+1, t+2$, and $t+3$, respectively. Robust standard errors clustered at the year level are reported in parentheses. $* * *, * *$, and * indicate significance at the $1 \%, 5 \%$, and $10 \%$ levels, respectively. Definitions of variables are in Appendix B.

Panel A: Free banks

\begin{tabular}{lcccccc}
\hline & \multicolumn{3}{c}{$\operatorname{Ln}($ Free bank counts) } & \multicolumn{3}{c}{ Free bank ratio } \\
\cline { 2 - 7 } & $\mathrm{t}+1$ & $\mathrm{t}+2$ & $\mathrm{t}+3$ & $\mathrm{t}+1$ & $\mathrm{t}+2$ & $\mathrm{t}+3$ \\
\cline { 2 - 7 } & $(1)$ & $(2)$ & $(3)$ & $(4)$ & $(5)$ & $(6)$ \\
\hline Free banking & $0.235^{* * *}$ & $0.209^{* * *}$ & $0.183^{* * *}$ & $0.038^{* * *}$ & $0.033^{* * *}$ & $0.031^{* * *}$ \\
& $(0.045)$ & $(0.047)$ & $(0.048)$ & $(0.009)$ & $(0.007)$ & $(0.007)$ \\
Ln(Population) & $-0.035^{* * *}$ & $-0.030^{* * *}$ & $-0.026^{* * *}$ & $-0.004^{* * *}$ & $-0.003^{* *}$ & $-0.003^{* *}$ \\
& $(0.010)$ & $\mathrm{a}(0.010)$ & $(0.009)$ & $(0.001)$ & $(0.001)$ & $(0.001)$ \\
Urban ratio & $0.638^{* * *}$ & $0.627^{* * *}$ & $0.587^{* * *}$ & $0.124^{* * *}$ & $0.126^{* * *}$ & $0.122^{* * *}$ \\
& $(0.165)$ & $(0.140)$ & $(0.133)$ & $(0.034)$ & $(0.027)$ & $(0.026)$ \\
Slave ratio & $-0.807^{* *}$ & $-0.787^{* * *}$ & $-0.691^{* * *}$ & $-0.151^{* * *}$ & $-0.143^{* * *}$ & $-0.124^{* * *}$ \\
& $(0.329)$ & $(0.277)$ & $(0.254)$ & $(0.054)$ & $(0.035)$ & $(0.032)$ \\
White ratio & $-2.084^{* * *}$ & $-2.034^{* * *}$ & $-1.883^{* * *}$ & $-0.367^{* * *}$ & $-0.357^{* * *}$ & $-0.328^{* * *}$ \\
& $(0.577)$ & $(0.493)$ & $(0.461)$ & $(0.099)$ & $(0.074)$ & $(0.071)$ \\
Constant & $2.111^{* * *}$ & $2.015^{* * *}$ & $1.841^{* * *}$ & $0.355^{* * *}$ & $0.338^{* * *}$ & $0.307^{* * *}$ \\
& $(0.573)$ & $(0.501)$ & $(0.465)$ & $(0.094)$ & $(0.071)$ & $(0.068)$ \\
Observations & 748 & 748 & 748 & 748 & 748 & 748 \\
R-squared & 0.454 & 0.421 & 0.389 & 0.426 & 0.394 & 0.378 \\
State FE & Yes & Yes & Yes & Yes & Yes & Yes \\
Year FE & Yes & Yes & Yes & Yes & Yes & Yes \\
\hline
\end{tabular}


Panel B: Free bank loans

\begin{tabular}{lcccccc}
\hline & \multicolumn{3}{c}{ Ln(Free bank loans) } & \multicolumn{3}{c}{ Free bank loan ratio } \\
\cline { 2 - 7 } & $\mathrm{t}+1$ & $\mathrm{t}+2$ & $\mathrm{t}+3$ & $\mathrm{t}+1$ & $\mathrm{t}+2$ & $\mathrm{t}+3$ \\
\cline { 2 - 7 } & $(1)$ & $(2)$ & $(3)$ & $(4)$ & $(5)$ & $(6)$ \\
\hline Free banking & $2.894^{* * *}$ & $2.924^{* * *}$ & $2.947^{* * *}$ & $0.007^{* * *}$ & $0.008^{* * *}$ & $0.009^{* * *}$ \\
& $(0.691)$ & $(0.698)$ & $(0.702)$ & $(0.002)$ & $(0.002)$ & $(0.002)$ \\
Ln(Population) & $-0.332^{* * *}$ & $-0.319^{* * *}$ & $-0.300^{* *}$ & $-0.001^{* * *}$ & $-0.000^{* * *}$ & $-0.000^{* *}$ \\
& $(0.112)$ & $(0.112)$ & $(0.114)$ & $(0.000)$ & $(0.000)$ & $(0.000)$ \\
Urban ratio & $8.193^{* * *}$ & $8.840^{* * *}$ & $9.761^{* * *}$ & $0.025^{* * *}$ & $0.029^{* * *}$ & $0.033^{* * *}$ \\
& $(2.683)$ & $(2.642)$ & $(2.257)$ & $(0.008)$ & $(0.009)$ & $(0.008)$ \\
Slave ratio & $-10.585^{* *}$ & $-11.373^{* *}$ & $-12.154^{* * *}$ & $-0.030^{* *}$ & $-0.035^{* *}$ & $-0.039^{* * *}$ \\
& $(4.821)$ & $(4.622)$ & $(3.824)$ & $(0.014)$ & $(0.014)$ & $(0.012)$ \\
White ratio & $-26.118^{* * *}$ & $-28.402^{* * *}$ & $-30.940^{* * *}$ & $-0.073^{* * *}$ & $-0.082^{* * *}$ & $-0.092^{* * *}$ \\
& $(8.964)$ & $(8.718)$ & $(7.419)$ & $(0.025)$ & $(0.026)$ & $(0.024)$ \\
Constant & $25.699^{* * *}$ & $27.322^{* * *}$ & $29.035^{* * *}$ & $0.070^{* * *}$ & $0.077^{* * *}$ & $0.084^{* * *}$ \\
& $(8.679)$ & $(8.377)$ & $(7.249)$ & $(0.024)$ & $(0.024)$ & $(0.023)$ \\
Observations & 730 & 712 & 694 & 730 & 712 & 694 \\
R-squared & 0.402 & 0.403 & 0.404 & 0.334 & 0.357 & 0.376 \\
State FE & Yes & Yes & Yes & Yes & Yes & Yes \\
Year FE & Yes & Yes & Yes & Yes & Yes & Yes \\
\hline
\end{tabular}

Panel C: Innovation

\begin{tabular}{lccc}
\hline & \multicolumn{3}{c}{$\operatorname{Ln}($ Patents) } \\
\cline { 2 - 4 } & $\mathrm{t}+1$ & $\mathrm{t}+2$ & $\mathrm{t}+3$ \\
\cline { 2 - 4 } & $(1)$ & $(2)$ & $(3)$ \\
\hline Free banking & $0.191^{* *}$ & $0.270^{* * *}$ & $0.247^{* * *}$ \\
& $(0.090)$ & $(0.083)$ & $(0.083)$ \\
Ln(Population) & $0.315^{* * *}$ & $0.412^{* * *}$ & $0.516^{* * *}$ \\
& $(0.064)$ & $(0.086)$ & $(0.102)$ \\
Urban ratio & 0.805 & 1.418 & 2.326 \\
& $(1.167)$ & $(1.492)$ & $(1.414)$ \\
Slave ratio & $4.114^{* *}$ & 2.043 & -0.208 \\
& $(1.553)$ & $(1.949)$ & $(2.086)$ \\
White ratio & $6.590^{* * *}$ & $5.135^{* * *}$ & $3.423^{*}$ \\
& $(1.711)$ & $(1.897)$ & $(1.944)$ \\
Constant & $-9.367^{* * *}$ & $-8.850^{* * *}$ & $-8.371^{* * *}$ \\
Observations & $(1.562)$ & $(1.520)$ & $(1.540)$ \\
R-squared & 748 & 748 & 748 \\
State FE & 0.810 & 0.802 & 0.795 \\
Year FE & Yes & Yes & Yes \\
\hline
\end{tabular}

